Issued by Sandia National Laboratories, operated for the United States Department of Energy by Sandia Corporation.

NOTICE: This report was prepared as an account of work sponsored by an agency of the United States Government. Neither the United States Government nor any agency thereof, nor any of their employees, nor any of their contractors, subcontractors, or their employees, makes any warranty, express or implied, or assumes any legal liability or responsibility for the accuracy, completeness, or usefulness of any information, apparatus, product, or process disclosed, or represents that its use would not infringe privately owned rights. Reference herein to any specific commercial product, process, or service by trade name, trademark, manufacturer, or otherwise, does not necessarily constitute or imply its endorsement, recommendation, or favoring by the United States Government, any agency thereof, or any of their contractors or subcontractors. The views and opinions expressed herein do not necessarily state or reflect those of the United States Government, any agency thereof, or any of their contractors.

Printed in the United States of America. This report has been reproduced directly from the best available copy.

Available to DOE and DOE contractors from

Office of Scientific and Technical Information

P.O. Box 62

Oak Ridge, TN 37831

Prices available from (615) 576-8401, FTS 626-8401

Available to the public from

National Technical Information Service

U.S. Department of Commerce

5285 Port Royal Rd

Springfield, VA 22161

NTIS price codes

Printed copy: A05

Microfiche copy: A01

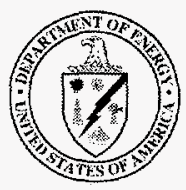




\title{
National Environmental Policy Act (NEPA) Compliance at Sandia National Laboratories/New Mexico (SNL/NM)
}

\author{
Theodore A. Wolff \\ Community Involvement and Issues Management Department \\ Sandia National Laboratories \\ P. O. Box 5800 \\ Albuquerque, New Mexico 87185-1313 \\ and \\ Roger P. Hansen \\ Hansen Environmental Consultants \\ $6439 B$ South Havana Street \\ Englewood, Colorado 80111-5618
}

\begin{abstract}
This report on National Environmental Policy Act (NEPA) compliance at Sandia National

Laboratories/New Mexico (SNL/NM) chronicles past and current compliance activities and includes a recommended strategy that can be implemented for continued improvement. This report provides a list of important references. Attachment I contains the table of contents for SAND95-1648, National Environmental Policy Act (NEPA) Compliance Guide Sandia National Laboratories (Hansen, 1995). Attachment II contains a list of published environmental assessments (EAs) and environmental impact statements (EISs) prepared by SNL/NM. Attachment III contains abstracts of NEPA compliance papers authored by SNL/NM and its contractors.
\end{abstract}

DISTRBBUTION OF THS DOCUMENT IS UNUMITE 


\section{Preface}

This report reflects the views and experiences of the authors. T. A. Wolff, Ph.D., has been involved in National Environmental Policy Act (NEPA) compliance activities at Sandia National Laboratories/New Mexico (SNL/NM) since 1981. In 1981, he helped prepare NEPA documents for inactive uranium mill tailings sites for which the U.S. Department of Energy (DOE) had assessment and restoration responsibilities under the Uranium Mill Tailings Radiation Control Act of 1978. In 1989, Wolff organized SNL/NM's NEPA Compliance Team and served as its team leader until 1997. R. P. Hansen, J. D., has supported NEPA compliance activities at SNL/NM since 1987. He prepared several environmental assessments (EAs) for SNL/NM and DOE and authored SAND95-1648, National Environmental Policy Act (NEPA) Compliance Guide Sandia National Laboratories (Hansen, 1995), gathered baseline information, and participated in NEPA training seminars. 


\section{DISCLAIMER}

Portions of this document may be illegible electronic image products. Images are produced from the best available original document. 
This page intentionally left blank. 


\section{National Environmental Policy Act (NEPA) Compliance at Sandia National Laboratories/New Mexico (SNL/NM)}

\section{Table of Contents}

Abstract

Preface

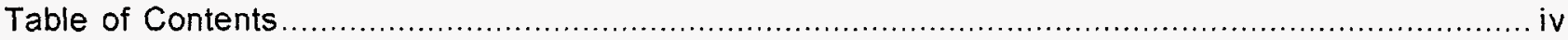

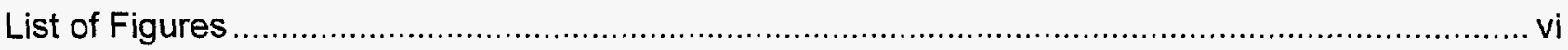

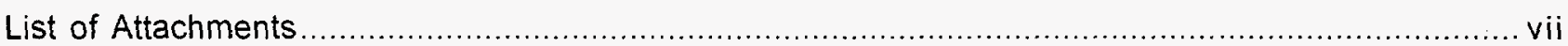

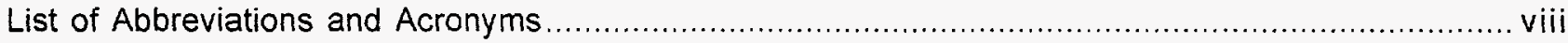

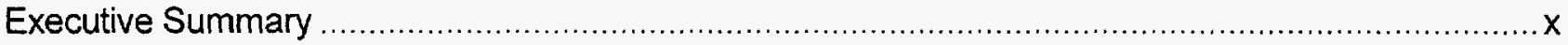

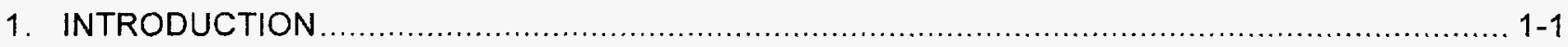

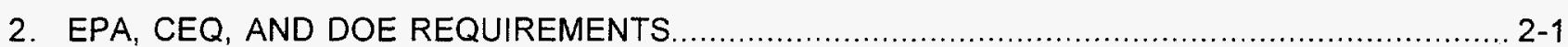

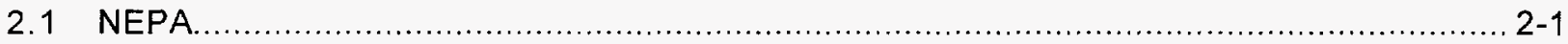

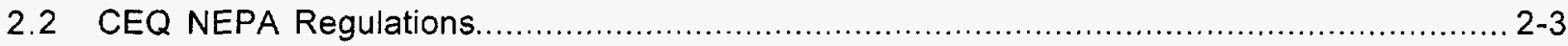

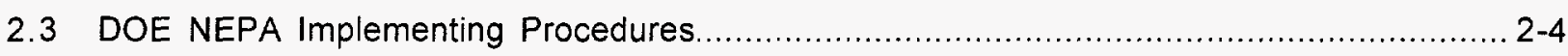

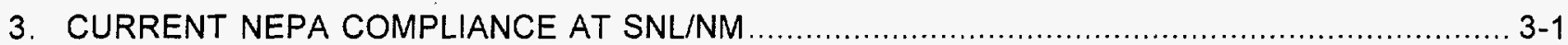

4. SUGGESTED STRATEGY FOR IMPROVING NEPA COMPLIANCE AT SNL/NM ................... 4-1

4.1 Element 1: Enhance Integration of NEPA Compliance With Other ES\&H Activities and Support Programs

4.2 Element 2: Increase NEPA Compliance Outreach, Training, and Support to Line Organizations

4.3 Element 3: Assist DOE In Shortening the Decision Time for Determining the Level of NEPA Documentation for Any Project

4.4 Element 4: Support Further Development and Use of Broad-Scope "Umbrella" NEPA

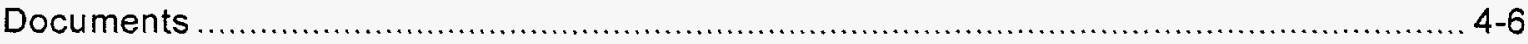

4.5 Element 5: Prepare and Update Environmental "Baseline" Information ......................... 4-9

4.6 Element 6: Support Earlier and More Comprehensive Internal DOE and SNL/NM Scoping of NEPA Documents

4.7 Element 7: Support Efficient and Effective Public Scoping of EISs That Minimizes Confrontation

4.8 Element 8: Prepare Detailed Annotated Outlines for Future EAs and EISs.

4.9 Element 9: Support Increased Integration of DOE and Air Force NEPA Compliance Requirements.

4.10 Element 10: Improve NEPA Compliance and Records Management.

4.11 Element 11: Prepare Shorter and More Readable NEPA Documents. 
Table of Contents (Continued)

5. THE SITE-WIDE ANALYSIS APPROACH TO NEPA COMPLIANCE

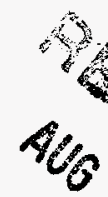

5.1 CEQ Requirements.

5.2 The DOE Site-wide NEPA Review Process.

5.2.1 Site-wide NEPA Review at the Kauai Test Facility (KTF)

$5-2$

5.2.2 Site-wide NEPA Review for the Environmental Restoration (ER) Project.

6. INTEGRATION OF NEPA COMPLIANCE WITH OTHER ENVIRONMENTAL LAWS AND REVIEW PROCESSES

6.1 Integration of NEPA Compliance With Other Environmental Laws $6-1$

6.2 Integration of NEPA Compliance With Other Review Processes 6-3

6.2.1 U.S. Air Force (USAF) NEPA Process. 6-3

6.2.2 Biological Review Process 6-4

6.2.3 Cultural Resource Review Process. 6-6

7. NEPA TRAINING ACTIVITIES AND SNL/NM 7-1

8. CONCLUSION. 8-1

9. REFERENCES 9-1 


\section{List of Figures}

\section{Figure Tit/e}

Figure $1 \quad$ NEPA Document Decision Process......................................................... 2-5

Figure 2 ECL/ADM Process Flow Chart ............................................................ 4-5

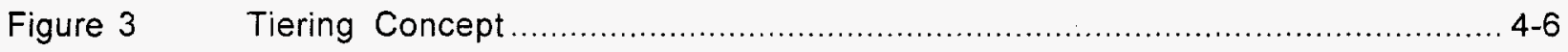

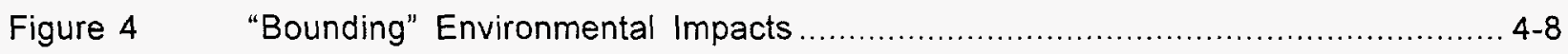




\section{List of Attachments}

\begin{tabular}{|c|c|}
\hline Attachments & Tit/e \\
\hline 1 & NEPA Compliance Guide Table of Contents. \\
\hline II & List of Published EAs and EISs for SNL/NM. \\
\hline III & Abstracts of Published Reports and Journal Articles \\
\hline
\end{tabular}




\section{List of Abbreviations and Acronyms}

ACHP Advisory Council on Historic Preservation

ADM action description memorandum

AFI Air Force Instruction

AHPA Archaeological and Historic Preservation Act

AIRFA American Indian Religious Freedom Act

ARPA Archaeological Resources Protection Act

ISO

International Organization for Standardization

CAA Clean Air Act

CEQ

Council on Environmental Quality

CERCLA Comprehensive Environmental Response, Compensation and Liability Act

CFR

Code of Federal Regulations

CWA Clean Water Act

CX

categorical exclusion

D\&D decontamination and decommissioning

DEIS draft environmental impact statement

DoD Department of Defense

DOE Department of Energy

DOE-AL Department of Energy-Albuquerque Operations Office

DOE-HQ Department of Energy-Headquarters

DOPAA description of the proposed action and alternatives

EO

executive order

EA

environmental assessment

EIA

environmental Impact Assessment

$E C L$

environmental checklist

EIAP

environmental impact analysis process

ED

environmental information document

ES

environmental impact statement

由

environmental restoration

ES\&H environment, safety, and health

ESA Endangered Species Act

FHA Federal Highway Administration

FOIA Freedom of Information Act

FONSI finding of no significant impact 


\section{List of Abbreviations and Acronyms (Continued)}

R Federal Register

INEEL Idaho National Engineering and Environmental Laboratory

KAFB Kirtland Air Force Base

KFC Kirtland Federal Complex

$\mathrm{KAO}$ DOE Kirtland Area Office

KTF Kauai Test Facility

LLNL Lawrence Livermore National Laboratory

MAP mitigation action plan

NAGPRA Native American Graves Protection and Repatriation Act

NEPA National Environmental Policy Act

NHPA National Historic Preservation Act

NMDGF New Mexico Department of Game and Fish

$\mathrm{NO} \quad$ notice of intent

NRHP National Register of Historic Places

PMRF Pacific Missile Range Facility

RCRA Resource Conservation and Recovery Act

RFICMS Resource Conservation and Recovery Act (RCRA) facility investigation/corrective measures

RFP request for proposal

ROD record of decision

SDWA Safe Drinking Water Act

SHPO state historic preservation officer

SWEIS site-wide environmental impact statement

SNL Sandia National Laboratories

SNLNM Sandia National Laboratories/New Mexico

SNL/CA SNL/Livermore, California

TAS Technical Advisory Subcommittee

TE threatened or endangered

USAF U.S. Air Force

USFS U.S. Forest Service

U.S.C. United States Code

USFWS U.S. Fish and Wildlife Service 


\section{EXECUTIVE SUMMARY}

This report on National Environmental Policy Act (NEPA) compliance at Sandia National Laboratories/New Mexico (SNL/NM) chronicles past and current compliance activities and presents a recommended strategy that can be implemented for continued improvement.

The purposes of this report and its general scope are provided in Section I, Introduction. Section 2 summarizes NEPA, the Council on Environmental Quality (CEQ) NEPA implementing regulations, and the U.S. Department of Energy (DOE) NEPA compliance procedures. Section 2.1 discusses the relationship between the NEPA policy objectives established by Congress in NEPA $\$ 101$ and the better-known requirements for preparation of environmental impact statements (EISs) in $\$ 102$. Section 2.2 briefly addresses the NEPA implementation regulations of the CEQ, which has primary responsibility for implementing the Act. Section 2.3 provides background information for the DOE NEPA procedures in 10 CFR Part 1021 and the Secretarial Policy on National Environmental Policy (NEPA) (U.S. Department of Energy, 1994a).

Section 3 addresses current NEPA compliance at SNL/NM and explains the NEPA compliance roles and responsibilities of the SNL/NM Environment, Safety and Health (ES\&H) Center, line organizations, and NEPA professionals who provide guidance and assistance. This section of the report also explains the role of the comprehensive Sandia National Laboratories (SNL) SAND95-1648, National Environmental Policy Act (NEPA) Compliance Guide: Sandia National Laboratories (Hansen, 1995).

A suggested strategy for improving NEPA compliance at SNL/NM is discussed in detail in Section 4. The strategy consists of 11 elements that are discussed individually. They include: (1) enhancing the integration of NEPA compliance with other ES\&H activities; (2) increasing NEPA training and support to line organizations; (3) shortening the decision time for determining the appropriate level of NEPA documentation; (4) accelerating the use of broad omnibus or "umbrella" documents; (5) preparing and updating "baseline" environmental information for use in NEPA documents; (6) supporting more effective internal environmental assessment (EA) and environmental impact statement (EIS) scoping; (7) developing public EIS scoping techniques that minimize confrontation; (8) encouraging the preparation of detailed annotated outlines for all EAs and EISs; (9) improving the integration of DOE and U.S. Air Force (USAF) NEPA compliance procedures; (10) improving NEPA compliance and documentation records management; and (11) preparing shorter and more readable NEPA documents. 
Section 5.0 addresses the site-wide analysis approach to NEPA compliance and related CEQ and DOE requirements. Examples of SNL/NM site-wide documents, including the Kauai Test Facility (KTF) EA and the Environmental Restoration (ER) Project EA, are summarized.

Section 6.0 discusses integration of NEPA compliance requirements with those of other environmental laws and regulations. This section also provides examples of the integration of NEPA documents with the USAF NEPA process, biological resources review, and cultural resources review.

Attachment I contains the table of contents for SAND95-1648, National Environmental Policy Act (NEPA) Compliance Guide: Sandia National Laboratories (Hansen, 1995). Attachment II provides a list of published EAs and EISs. Attachment III contains abstracts of NEPA compliance papers authored by SNL/NM and NEPA contractor professionals. 
This page intentionally left blank 


\section{INTRODUCTION}

The National Environmental Policy Act NEPA ${ }^{1}$ is the nation's most comprehensive legislative and public policy statement on protection of the environment. It has been referred to by some authors as an "environmental Magna Carta"." Passed in 1969 on the eve of Earth Day 1970, the Act established a philosophical and policy context for such later major Congressional initiatives as the Clean Air Act (CAA), Clean Water Act (CWA), Safe Drinking Water Act (SDWA), and Endangered Species Act (ESA). In fact, NEPA preceded by over 10 years implementation of hazardous waste laws embodied in the Resource Conservation and Recovery Act (RCRA) and the Comprehensive Environmental Response, Compensation and Liability Act (CERCLA) ${ }^{3}$. Thus, SNL/NM was supporting the U.S. Department of Energy's (DOE's) compliance with NEPA long before hazardous, radioactive, and mixed waste management became a public regulatory issue.

This report has a two-fold purpose: (1) acquaint Sandia National Laboratories/New Mexico (SNL/NM) and DOE personnel, as well as the public, with NEPA compliance activities; and (2) recommend an 11-point strategy for improved compliance in the future. An underlying objective is to resurrect interest in NEPA mandates with which DOE and SNL/NM must comply at a time when waste management activities are receiving most of the environmental attention. In fact, some environmental professionals now consider "waste management" and "environmental compliance" to be synonymous. Although waste management activities are important, failure to adequately comply with NEPA can result in DOE and SNL/NM project delays and legal challenges.

Section 2.0 includes a brief review of NEPA, Council on Environmental Quality (CEQ), and DOE requirements. Section 3.0 reviews the current NEPA compliance practice at SNL/NM. Section 4.0 details the eleven elements of a recommended strategy for improving NEPA compliance, and Section 5.0 presents a site-wide analysis approach with examples. Section 6.0 discusses NEPA "streamlining" through consolidated compliance with other environmental laws. Attachment $I$ contains the table of contents of the National Environmental Policy Act (NEPA) Compliance Guide: Sandia National Laboratories (Hansen, 1995). Attachment II provides a list of published environmental impact statements (EIS) and environmental assessments (EA) prepared by SNL/NM. Attachment III contains abstracts of reports and journal articles published by SNL/NM NEPA professionals and contractors.

\footnotetext{
142 USC 4321 et seq.

2 Mandelker, D. R., 1997 "NEPA Law and Litigation," \$1.01, Clark Boardman Callahan, New York, NY.

${ }^{3}$ Although RCRA was enacted by Congress in 1976, the initial regulations on hazardous waste management were not promulgated until May 19, 1980. CERCLA was also enacted in 1980.
} 


\section{NEPA, CEQ, AND DOE REQUIREMENTS}

This section briefly discusses NEPA, the CEQ implementing regulations, and the DOE implementing procedures. For more detail on these regulations, see (Hansen, 1995) and other literature.

\subsection{NEPA}

NEPA, 42 U.S.C $\$ 4321$ et seq., applies to "all agencies of the Federal Government" including DOE. As a DOE contractor, Sandia Corporation, which operates SNLNM and SNL/CA, provides NEPA compliance support to DOE.

NEPA is a centerpiece of U.S. environmental law. It gives the federal government both the authority and the means to protect the environment. Federal agencies must evaluate the environmental consequences of proposed actions and consider alternative ways of proceeding. However, the majority of federal court decisions have held that NEPA requires agencies to follow the procedures required by the Act rather than to make substantive decisions favoring environmental protection or implementing NEPA policy objectives.

For example, in a U.S. Supreme Court decision, Robertson vs. Methow Valley Citizens Council, [490 U.S. 332,349 (1989)], the Court stated:

"NEPA itself does not impose substantive duties mandating particular results but simply prescribes the necessary process for preventing uninformed---rather than unwise--agency action .... If the adverse environmental effects of the proposed action are adequately identified and evaluated, the agency is not constrained by NEPA from deciding that other values outweigh the environmental costs."

Although NEPA requires only environmentally informed decisions and not particular results, it is assumed that better decisions will flow from good environmental information. Thus, NEPA is designed to positively influence the decision-making process without usurping agency prerogatives.

Under NEPA, federal agencies are mandated to produce scientifically credible analyses that comply with NEPA, the CEQ regulations, and the agency's own NEPA implementing procedures. The substantive environmental goals of NEPA $\S 101(\mathrm{~b})$ are linked to the procedural duties of NEPA $\S 102(2)(C)$. These goals require that federal agencies have a "continuing responsibility" to use "all practicable means" to: 
- Fulfill the responsibility of each generation as "trustee" of the environment.

- Assure all Americans that they have access to safe, healthful, productive, and aesthetically and culturally pleasing surroundings.

- Attain the "widest range of beneficial uses" of the environment without degradation.

- Preserve important historic, cultural, and natural aspects of the national heritage.

- Achieve a "balance" between population and resource use.

- Enhance the quality of renewable resources.

NEPA requires that agencies prepare a "detailed statement"-now known as the environmental impact statement (EIS) -on proposals for "major federal actions significantly affecting the quality of the human environment." 4 This EIS requirement is the principal "action-forcing" mechanism of NEPA. Whether or not an action is a major federal action significantly affecting the human environment is discussed by Wolff and Hansen (1993 and 1996) and March 1996 (see Attachment III).

Proponents of proposed actions may be uncertain regarding the need to comply with NEPA when they believe that the impacts of their proposed actions are beneficial. However, the CEQ regulations in 40 CFR $§ 1508.27(b)(1)$ state:

"Impacts may be both beneficial and adverse. A significant effect may exist even if the Federal agency believes that on balance the effect will be beneficial."

Federal agencies or their contractors prepare other types of NEPA compliance documentation in addition to the EIS. The most common of these is the environmental assessment (EA) and, when applicable, the finding of no significant impact (FONSI). Many agencies prepare NEPA compliance checklists and other types of internal documents. For example, SNL/NM routinely prepares environmental checklists (ECLs) and action description memoranda (ADMs) to assist $D O E$ in determining the significance of proposed actions. Although each federal agency has its

${ }^{4}$ NEPA $\$ 101$ (2) (C); (42 U.S.C. 4332 (2) (C) 
Own NEPA procedures, implementing the Act's requirements is the primary responsibility of the CEQ. ${ }^{5}$

\subsection{CEQ NEPA Regulations}

The CEQ was established in 1970 within the Executive Office of the President under Title II of NEPA. Initially, the CEQ implemented NEPA through a series of "guidelines" for federal agencies. The guidelines were revised and published as regulations on November 28, 1978 (43 FR 55990) and are contained in 40 CFR Parts 1500 through 1508. The CEQ regulations had one minor amendment on April 25, 1986 (51 FR 15625).

DOE NEPA implementing procedures in $10 \mathrm{CFR} \S 1021.101$ state that it is DOE policy to "follow the letter and spirit of NEPA" and to "comply fully" with the CEQ regulations. DOE adopts the CEQ regulations in their entirety in $\$ 1021.103$. In other words, DOE facilities like SNL/NM must follow both the CEQ and DOE NEPA compliance requirements. It is not sufficient for NEPA practitioners to follow only DOE regulations and guidance documents while ignoring CEQ requirements.

The CEQ regulations provide detailed requirements on a number of topics related to preparing EISs, EAs, findings of no significant impact (FONSIs), notices of intent (NOIs) to prepare an EIS, and agency records of decision (RODs). These include, but are not limited to: public scoping of an EIS; EIS and EA format and content; public and agency commenting on draft EISs; other public involvement; agency decision making; writing and reducing paperwork; using an interdisciplinary approach; and integrating other environmental review requirements in the NEPA process. The CEQ regulations also define 27 terms that are used extensively in the NEPA compliance process (e.g., "cumulative impact," "major federal action," "significantly," "human environment"). In preparing its own NEPA implementing procedures and internal guidance, DOE relies heavily on the CEQ mandates and interpretations.

In addition to the regulations, the CEQ has published NEPA compliance guidance on two occasions: March 23, 1981 (46 FR 18026) and July 28, 1983 (48 FR 34263). However, the guidance is generally limited to responses to inquiries concerning the regulations.

\footnotetext{
${ }^{5}$ E.O.11514. March 5, 1970 Protection and Enhancement of Environmental Quality as amended by E.O. 11991. (Secs 2(g) and (39h)). May 24, 1977.
} 


\subsection{DOE NEPA Implementing Procedures}

The CEQ requires that federal agencies adopt their own procedures to conform to NEPA and the CEQ regulations (40 CFR $\S \S 1505.1$ and 1507.3). The procedures of individual agencies are considered as a supplement to the CEQ regulations, not a substitute. The NEPA document decision process as applied to DOE is shown in Figure 1. 


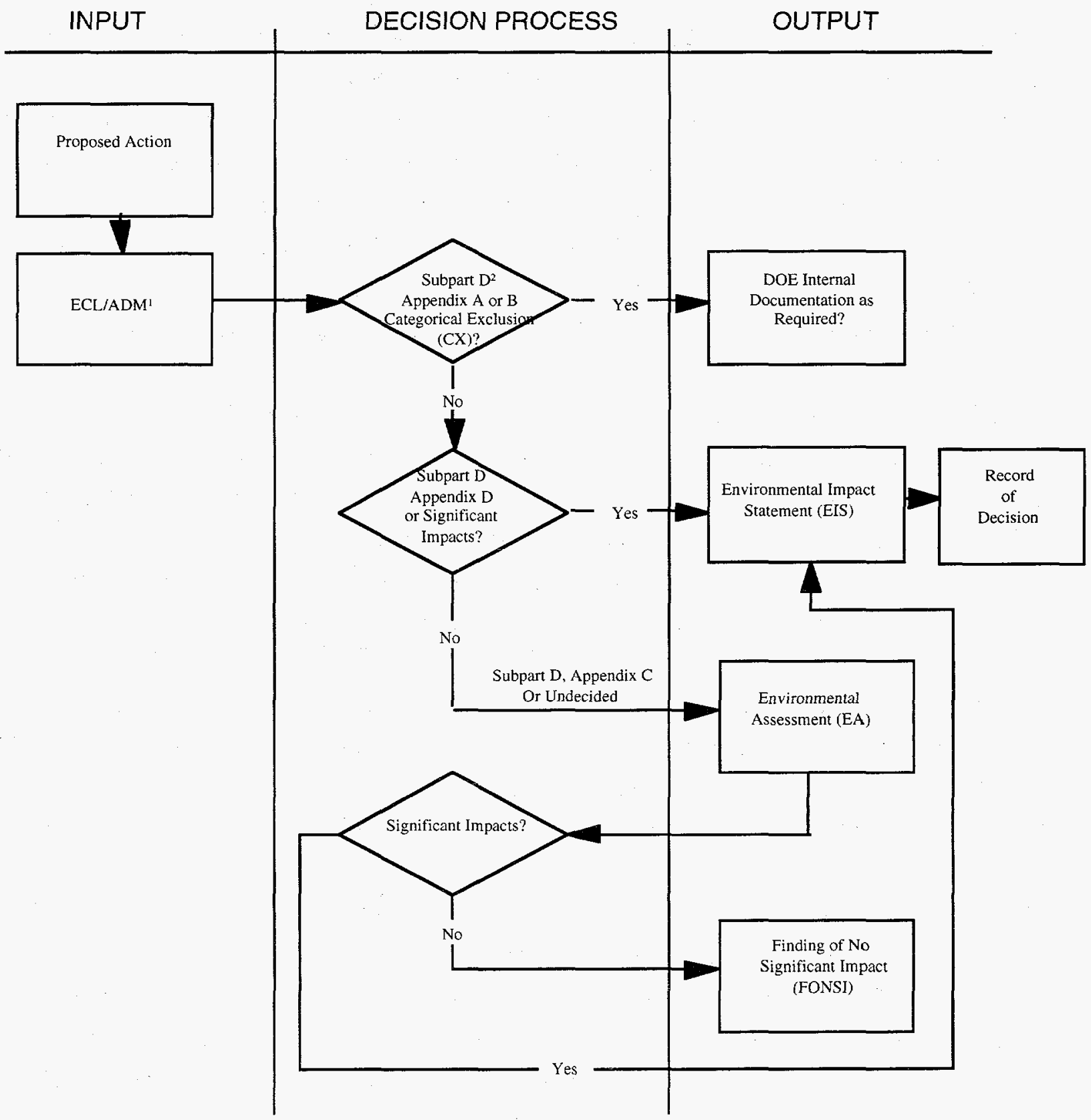

${ }^{1}$ ECLAADM - Environmental Checklist/Action Description Memorandum

2Subpart D of DOE NEPA Procedures (10 CFR Part 1021)

${ }^{3}$ Appendix A of 10 CFR Part L021. Subpart D. lists categorical exclusions that apply to general (e.g., administrative) actions with potential impacts too Remote and conjectural to be meaningfully analyzed. An Appendix A CX determination does not require DOE internal documentation.

Figure 1. NEPA Document Decision Process 
DOE's extensively revised and rewritten NEPA implementing procedures were published in the Federal Register on April 24, 1992 (52 FR 15122) and revised on July 9, 1996 (61 FR 36222). They entirely replace the old 10 CFR Part 1021 NEPA procedures that were published on December 15, 1987, as amended (52 FR 47662). The 1996 amendments incorporate changes intended to improve DOE's efficiency in implementing NEPA requirements by reducing costs and preparation time while maintaining quality, which is consistent with the DOE Secretarial Policy on National Environmental Policy Act (NEPA) issued in June 1994 (U.S. Department of Energy, 1994a). Most of the amendments pertain to the Subpart D, Appendix B, List of Categorical Exclusions, which are classes of actions that normally do not require either an EA or an EIS.

In addition to containing a detailed list of categorical exclusions, the new DOE NEPA implementing procedures address a wide range of topics, such as: agency review and public participation ( $\$ 1021.301)$; notice of intent and scoping ( $\$ 1021.311)$; public review of EISs $(\$ 1021.313)$; supplemental EISs and a new document, the "supplement analysis" ( $\$ 1021.314)$; requirements for EAs and FONSIs ( $\$ 1021.321$ and $\$ 1021.322)$; programmatic and "site-wide" documents ( $\$ 1021.330)$; mitigation action plans (MAPs) ( $\$ 1021.331)$; and other topics.

In accordance with the CEQ NEPA regulations in 40 CFR $\$ 1507.3$, DOE consulted with the CEQ regarding both the 1992 NEPA implementing procedures and the 1996 amendments to the DOE NEPA regulations. As reported in those rules, CEQ found that the new DOE rules and amendments conformed with NEPA and the CEQ regulations (57 FR 15122, April 24, 1992).

Steps introduced by the Secretary's June 1994 NEPA policy (U.S. Department of Energy, 1994a) to make DOE actions more cost-effective, timely, and useful to DOE decision makers and the public led to DOE's NEPA Compliance Program winning the 1995 Federal Environmental Quality Award. This award was presented by the National Association of Environmental Professionals (NAEP) and the CEQ at the NAEP 20th Annual Conference and Exposition on June 11, 1995, in Washington, D.C. DOE was cited "for its actions to integrate environmental values into its agency mission and its commitment to excellence in environmental decision making." 


\section{CURRENT NEPA COMPLIANCE AT SNL/NM}

The DOE has been conducting activities at SNL/NM in compliance with the NEPA since the Act's inception in 1970. The first overall environmental assessment (EA) for ongoing SNL/NM operations, EIA/MA 77-1, was issued in May 1977 by the Energy Research and Development Administration (ERDA), the predecessor of the DOE. ${ }^{6}$ NEPA documents ${ }^{7}$ for proposed DOE actions at SNL/NM facilities were recently listed in an annotated bibliography (Harris, 1995a).

Sandia National Laboratories (SNL) also operates remote facilities at Livermore, California (SNL/CA), Tonopah, Nevada, and Kauai, Hawaii. The Livermore and Tonopah facilities were first assessed in omnibus EAs, including SAND75-0268, Omnibus $^{8}$ Environmental Assessment, (Energy Research and Development Administration [ERDA], 1975a) and EIA/MA/76-2, Environmental Assessment (Energy Research and Development Administration [ERDA], 1975b). SAND75-0268, Omnibus Environmental Assessment, was issued as a draft because it was subsequently decided to combine the SNL/CA EA and an assessment of Lawrence Livermore National Laboratory (LLNL) in an EIS. The most recent environmental impact statement (EIS) covering the continuing operation of LLNL and SNL/CA was issued as DOE/EIS-0157 in August 1992 (U.S. Department of Energy, 1992a).

A site-wide EA was also published for the Kauai Test Facility (KTF) in 1992 as DOE/EA-0492 (U.S. Department of Energy, 1992b). Section 5.4 discusses this assessment and its strategic value. A site-wide EIS (SWEIS) is currently under preparation for SNL/NM. NEPA documents for proposed DOE actions at SNL/NM facilities were recently listed in one document (Harris, 1995a).

At SNL/NM, NEPA programmatic responsibility resides within the Environment, Safety, and Health (ES\&H) Center. However, line organizations are best informed about their proposed actions and must carry out the projects analyzed under NEPA. Thus, line organizations are responsible for preparing adequate and timely NEPA documents with assistance from SNL NEPA specialists from

\footnotetext{
6 Under ERDA, Sandia National Laboratories was managed by American Telephone and Telegraph (AT\&T). It is now managed and operated for DOE by Sandia Corporation, a wholly owned subsidiary of the Lockheed Martin Corporation.

7 DOE defines a NEPA document to include a DOE Notice of Intent (NOI), EIS, Record of Decision (ROD), EA, Finding of No Significant Impact (FONSI), or any other document prepared pursuant to a requirement of NEPA or CEQ regulations [(10 CFR $\S 1021.104(\mathrm{~b}))]$.

${ }^{8}$ The term "omnibus" is no longer used by DOE. Recent EAs and EISs of broad scope that are programmatic in nature and that cover entire facilities in a single location are referred to as "site-wide" documents.
} 
the ES\&H Center. Responsibilities for NEPA compliance and related compliance responsibilities for sensitive species and historic properties appear in MN471001, ES\&H Manual, Chapter 13, Section A, "NEPA, Sensitive Species, and Historic Properties" (Harris, 1997).

The SNL/NM NEPA compliance mission can be summarized as follows:

- Provide SNL/NM with technical guidance for comprehensive compliance with NEPA; the National Historic Preservation Act (NHPA), 16 U.S.C. \$470 et seq.; the Endangered Species Act (ESA), 16 U.S.C. $\$ 1531$ et seq.; and related resource protection laws.

- Assess the significance of the environmental impacts of proposed SNL/NM actions.

- Inform the public that DOE has considered environmental concerns in its decision making.

- Implement DOE regulations and orders and CEQ regulations regarding compliance with NEPA and other environmental and resource protection laws and regulations.

- Assist DOE in determining the appropriate level of NEPA documentation for any proposed SNL/NM action.

In meeting its NEPA mission, SNL/NM NEPA practitioners perform the following:

- Maintain NEPA files to include all current and prior DOE NEPA orders, records, and guidance, and SNL/NM NEPA documentation.

- Coordinate all SNL/NM NEPA compliance activities with DOE.

- Provide guidance and assistance to SNL/NM project managers in preparing required NEPA documentation. This guidance includes: (1) SAND95-1648 National Environmental Policy Act (NEPA) Compliance Guide) Sandia National Laboratories (Hansen, 1995); (2) relevant sections of MN471001, ES\&H Manual; (3) other guidance documents; and (4) court opinions.

- Develop compliance tools, such as baseline reports, NEPA compliance guides, and electronic interfaces ${ }^{9}$. (Baseline reports are a repository of detailed information on the affected environment. They are building blocks with which good NEPA documents can be efficiently and effectively produced.)

- Provide training outreach through a series of courses that help Sandians effectively and efficiently meet NEPA requirements.

\footnotetext{
9 The CEQ's NEPAnet (http://ceq.eh.doe.gov/nepa/nepanet.htm), and the DOE NEPA Home Page (http://tisnt.eh.doe.gov/nepa/) and SNL's internal "EC-Help" (an electronic NEPA checklist with detailed help menus, etc.) are important recent electronic additions to the NEPA "tool chest." These electronic tools provide useful information and guide project proponents through the preparation of NEPA documentation.
} 
The comprehensive NEPA Compliance Guide cited above is an essential tool for preparing better documents that are less vulnerable to legal challenges. The Guide serves as a "road map" for NEPA practitioners who must otherwise search through the complex maze of NEPA-related statutes, regulations, executive orders, other guidance documents, and court opinions.

The NEPA Compliance Guide contains, among other things:

- A discussion of NEPA, CEQ regulations, and DOE NEPA implementing procedures, policy, and guidance.

- Guidance for preparing environmental checklists (ECLs), action description memoranda (ADMs), categorical exclusion (CX) determinations, EAs, findings of no significant impact (FONSIs), and EISs.

- Recommendations for dealing with NEPA documentation problems.

- Discussion of key NEPA compliance issues.

The guide is a valuable resource that can be used by line organization managers, project managers, NEPA professionals, and others with NEPA compliance responsibilities at SNL facilities.

In summary, the current NEPA compliance strategy at SNL/NM focuses on:

- Providing a single point of contact with DOE's NEPA organization.

- Advising and supporting line managers in preparing required NEPA documents.

- Ensuring maintenance of NEPA administrative records and tracking SNL proposals through the DOE process.

- Providing outreach and training.

- Providing NEPA compliance tools.

- Integrating other environmental review requirements in the NEPA process where possible.

- Providing quality assurance and technical review of SNL/ NM NEPA documents. 


\section{SUGGESTED STRATEGY FOR IMPROVING NEPA COMPLIANCE AT SNL/NM}

Sandia National Laboratories/New Mexico (SNL/NM) has made considerable progress over the past several years in improving and streamlining the National Environmental Policy Act (NEPA) process. However, much remains to be accomplished in order to prepare higher quality documents and make the entire NEPA process work better and cost less. The following are considered to be essential elements of an improved NEPA compliance strategy. Many of them cannot be accomplished in the near term, but will require a continuing effort over several years. Also, some of these elements require that the U.S. Department of Energy (DOE) take certain initiatives; they cannot be accomplished by SNL/NM alone. The strategy elements include the following (items do not appear in any particular order of priority):

- Element 1 - Enhance the integration of NEPA compliance with other environment, safety, and health (ES\&H) activities and support programs.

- $\quad$ Element 2 - Increase NEPA compliance outreach, training, and support to line organizations including that needed for NEPA document preparation.

- Element 3- Assist DOE in shortening the decision time for determining the appropriate level of documentation for any project or program.

- Element 4 - Accelerate support for further development and use of broad-scope or "umbrella" NEPA documents that can be used for tiering. ${ }^{10}$

- Element 5 - Prepare and update "baseline" environmental information for use in NEPA documents.

- Element 6 - Support earlier and more comprehensive internal DOE and SNL/NM scoping of environmental assessments (EAs) and environmental impact statements (EISs).

- Element 7 - Support more efficient and effective public scoping of EISs that is "user friendly" and minimizes confrontation.

- $\quad$ Element 8 - Encourage and support preparation of detailed annotated outlines for all future EAs and EISs.

- Element 9 - Support increased integration of DOE-Kirtland Area Office (DOE-KAO) and Kirtland Air Force Base (KAFB) NEPA compliance requirements.

- $\quad$ Element 10 - Improve NEPA compliance and documentation records management.

\footnotetext{
10 "Tiering," discussed in Section 4.2.6 of the NEPA Compliance Guide, refers to preparation of broad-scope EAs or EISs from which subsequent documents of narrower scope can be tiered.
} 
- Element 11 - Work diligently to influence the preparation of shorter and more readable NEPA documents.

These 11 elements are discussed in more detail below.

\subsection{Element 1: Enhance Integration of NEPA Compliance With Other ES\&H Activities and Support Programs}

Need: The policy of Sandia Corporation is to protect and preserve the environment and the safety and health of personnel, contractors, visitors, and the public. Sandia National Laboratories' (SNL's) corporate ES\&H Program mandates compliance with all applicable laws, regulations, and DOE orders and directives. The corporate ES\&H Program is described in detail in SNL's MN471001, ES\&H Manual (Sandia National Laboratories, 1998).

The NEPA documentation process (ECLs, ADMs, EAs, EISs, etc.) at SNL/NM includes identifying many other ES\&H requirements. In most cases, NEPA compliance and ES\&H Manual compliance cannot be separated. For this reason, there is a need to assist line organizations in integrating NEPA requirements with other related ES\&H requirements and vice versa. For example, the NEPA process must support and be integrated with facilities engineering activities, including real estate permitting, infrastructure construction and modification, and decontamination and decommissioning (D\&D) projects.

Background: Completion of NEPA documents usually relies on information developed outside of the ES\&H Center. By the same token, ES\&H information is often drawn from NEPA documents. Thus, NEPA documentation and ES\&H information cannot be developed in a vacuum.

Suggested Approach: Greater use should be made of Sandia's Internal Web as a tool for enhanced integration of NEPA documents with other ES\&H and environmental support programs. NEPA and ES\&H practitioners can accelerate information integration by storing and retrieving data in a format that is compatible with both NEPA and ES\&H purposes. For example, it is not efficient or cost-effective to describe regulatory requirements (e.g., air quality, water quality) in $E S \& H$ documents in one format and then describe the same requirements in a completely different format for NEPA purposes. Electronic computer tools, such as ECL/ADM HELP and Sandia's Integrated Safety Management System (ISMS) Software, can aid line organizations in using the NEPA process to identify regulatory and DOE order requirements pertaining to the proposed project. Section 6.0 of this report discusses the NEPA integration issue in more detail. 


\subsection{Element 2: Increase NEPA Compliance Outreach, Training, and Support to Line Organizations}

Need: NEPA practitioners need to increase outreach efforts to line organizations as well as incorporate new tools into ongoing NEPA training. In particular, there is a need for NEPA practitioners to render greater assistance in preparing NEPA documents.

Background: NEPA practitioners have developed and taught classes in NEPA awareness and requirements. These classes are designed to improve the efficiency of SNL organizations in integrating NEPA requirements into the planning process and preparing better NEPA documents.

Suggested Approach: NEPA practitioners should make a concerted effort to enroll SNL line staff in the NEPA training classes. They should continue to enhance class content and make the training more relevant to everyday practical needs.

NEPA training should be made available through Sandia's Internal Web, starting with ENV120, NEPA Awareness (McAllaster, 1997). Line managers should require appropriate NEPA training for line personnel.

An electronic tool for preparing the environmental checklist/action description memorandum, called ECL/ADM-HELP, could be introduced as part of ENV 121-1, Integrating NEPA into SNL Project Planning (McAllaster, 1997). Section 7.0 discusses NEPA training activities.

\subsection{Element 3: Assist DOE In Shortening the Decision Time for Determining the Level of NEPA Documentation for Any Project}

Need: Determining the appropriate level of NEPA documentation---EA, EIS, or categorical exclusion (CX)---is ultimately a DOE decision. Valuable time and resources can be consumed by SNL/NM while awaiting a DOE decision on the appropriate level of NEPA documentation for a proposal. The problem is sometimes acute when determining whether to prepare an EA or an EIS. There is a need to expedite the decision-making process.

Background: Figure 1 illustrates DOE's present NEPA documentation decision process. It usually, but not always, involves preparation by SNL/NM of an environmental checklist/action description memorandum (ECL/ADM) and/or a recommendation that an action should or should not be categorically excluded. Of course, DOE can decide to prepare an EA or EIS without using 
the ECL/ADM process, particularly for projects whose impacts are controversial or obviously potentially significant.

Suggested Approach: ECL/ADMs should not be prepared in a pro forma manner just to satisfy a particular format but should focus on potentially significant impacts that will influence DOE's EA or EIS determination.

The recommendation to DOE (see Figure 2) should succinctly summarize the ECL/ADM findings that most directly bear on the level of documentation required. The judgment as to whether the potential effects are or are not "significant" should be left to DOE. Downplaying or avoiding mention of potentially significant effects should always be avoided.

If the proposed action is a candidate for a CX, the entire three-step process outlined in $10 \mathrm{CFR}$ $\$ 1021.410$ should be utilized: (1) does the proposal "fit" within the class of actions listed in Subpart D, Appendix A or B?; (2) are there any "extraordinary circumstances" related to the proposal (e.g., controversy, unknown risks, unique environmental effects)?; and (3) is the proposal "connected" to other actions with potentially significant impacts or cumulatively significant impacts?

Using only the first step (does the proposal "fit" the CX list?) is inadequate. A project that might normally require a $C X$ may be accompanied by special circumstances that require discussion in an ECL/ADM or, more rarely, an EA or even an EIS. 
"Action Originator" Initiates NEPA Proces
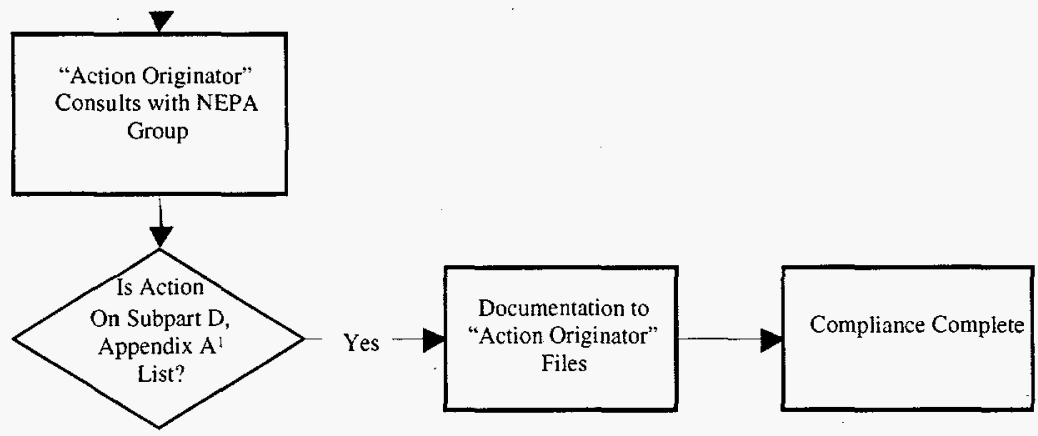

No

7

"Action Originator"

Prepares ECL/ADM

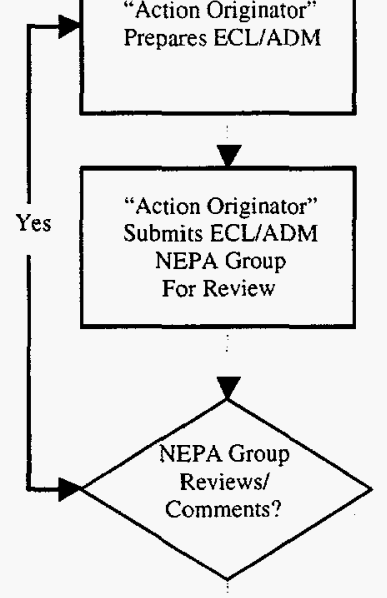

No

1

NEPA Group Assigns

Tracking Number and

Recommends

Documentation Level

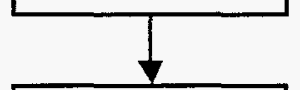
NEPA Group Forward Recommendation to DOE-KAO

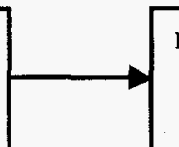

DOE-KAO² Determines Level of NEPA

Documentation
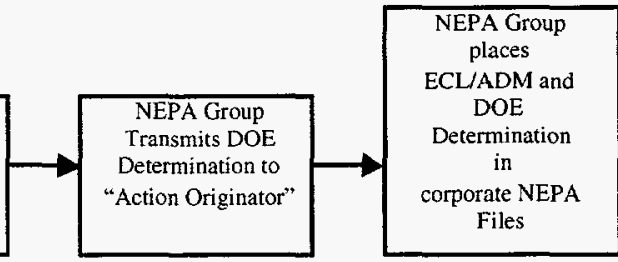

'DOE NEPA regulations in 10 CFT Part 1021

2In some cases, DOE-KAO may elevate determinations to DOE-AL

Figure 2. ECL/ADM Process Flow Chart 


\subsection{Element 4: Support Further Development and Use of Broad- Scope "Umbrella" NEPA Documents}

Need: SNL/NM NEPA practitioners and line organizations need to prepare broad-scope NEPA documents (EAs and EISs) that can be used for "tiering" as encouraged by the CEQ regulations in 40 CFR $\S 1502.20$. Preparation of umbrella documents will go a long way toward reducing the overall level-of-effort required for NEPA compliance. Preparing broad-scope documents is a key element of "streamlining" the NEPA process. It avoids needless preparation of often repetitive and redundant paperwork.

Background: "Tiering" as discussed in $\$ 1502.20$ of the CEQ regulations refers to the analysis of general issues addressed in broad-scope (programmatic) EISs followed by subsequent EISs or EAs of narrower scope (see NEPA Compliance Guide Section 4.2.6 [Hansen, 1995]). Figure 3 illustrates the tiering concept. However, tiering need not be confined to EISs and subsequent documents. A broad-scope EA can also be used as a tiering document. Whether the broadscope document is an EA or an EIS, subsequent documents of narrower scope need only summarize issues discussed in the broad-scope document or incorporate by reference the broad-scope document's discussion.

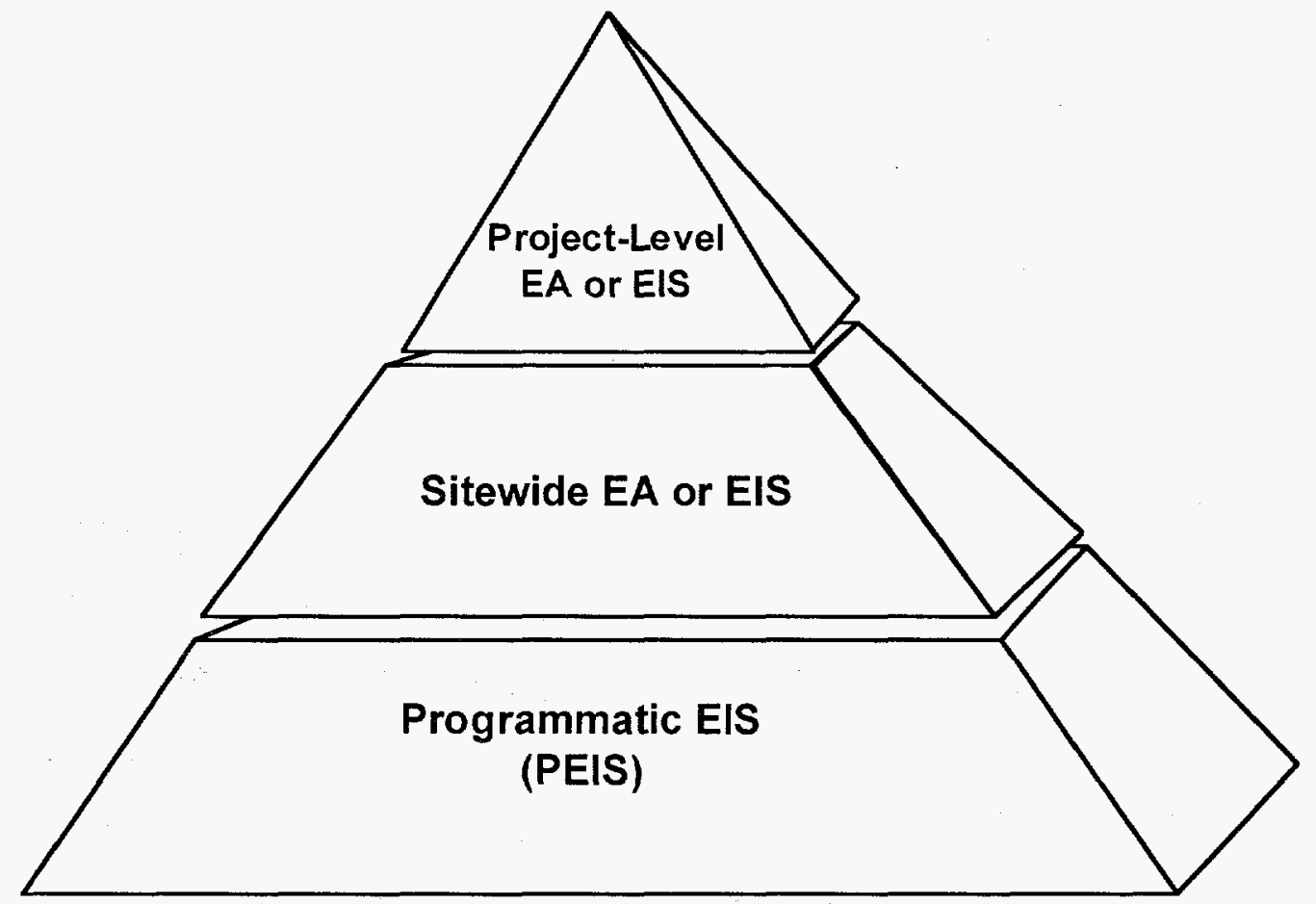

Figure 3. Tiering Concept 
The preparation of SNL/NM broad-scope documents such as the Kauai Test Facility (KTF) EA (U.S. Department of Energy, 1992b) has provided a competitive advantage to SNL in obtaining projects and programs. It has also resulted in significant savings of time and resources. The broad-scope SNL/NM Environmental Restoration (ER) EA (U.S. Department of Energy, 1995) can also be used as a tiering document for site-specific cleanup projects of smaller scope.

Suggested Approach: SNL line managers and NEPA professionals should take advantage of every opportunity to prepare broad-scope documents, particularly EAs. Subsequent documents or updates can then be tiered from these broad-scope documents. For example, the KTF EA could be updated by including new activities in another document and incorporating the existing EA by reference for most major issues (e.g., cultural resources, noise, and threatened and endangered [T/E] species ${ }^{11}$ ). The new EA could also tier from the programmatic Pacific Missile Range Facility Enhanced Capability Environmental Impact Statement now being prepared by the Department of Defense (DoD).

Broad-scope ECL/ADMs should also be prepared where possible to avoid having to discuss the same issues repeatedly in documents addressing the same types of projects. By "capturing" or "enclosing" actions with impacts of the greatest significance, bounding of impacts with "umbrella" documents helps ensure that all "reasonably foreseeable impacts" are included.

Figure 4 illustrates this concept. Note: each "Activity" is part of an overall action. Activities 11 and 12 are not bounded the EA or EIS and require separate NEPA documentation. See Wolff and Hansen, 1994.

\footnotetext{
${ }^{11}$ The KTF exists as a DOE tenant facility on the Hawaiian Island of Kauai within the boundaries of DoD Pacific Missile Range Facility (PMRF).
} 


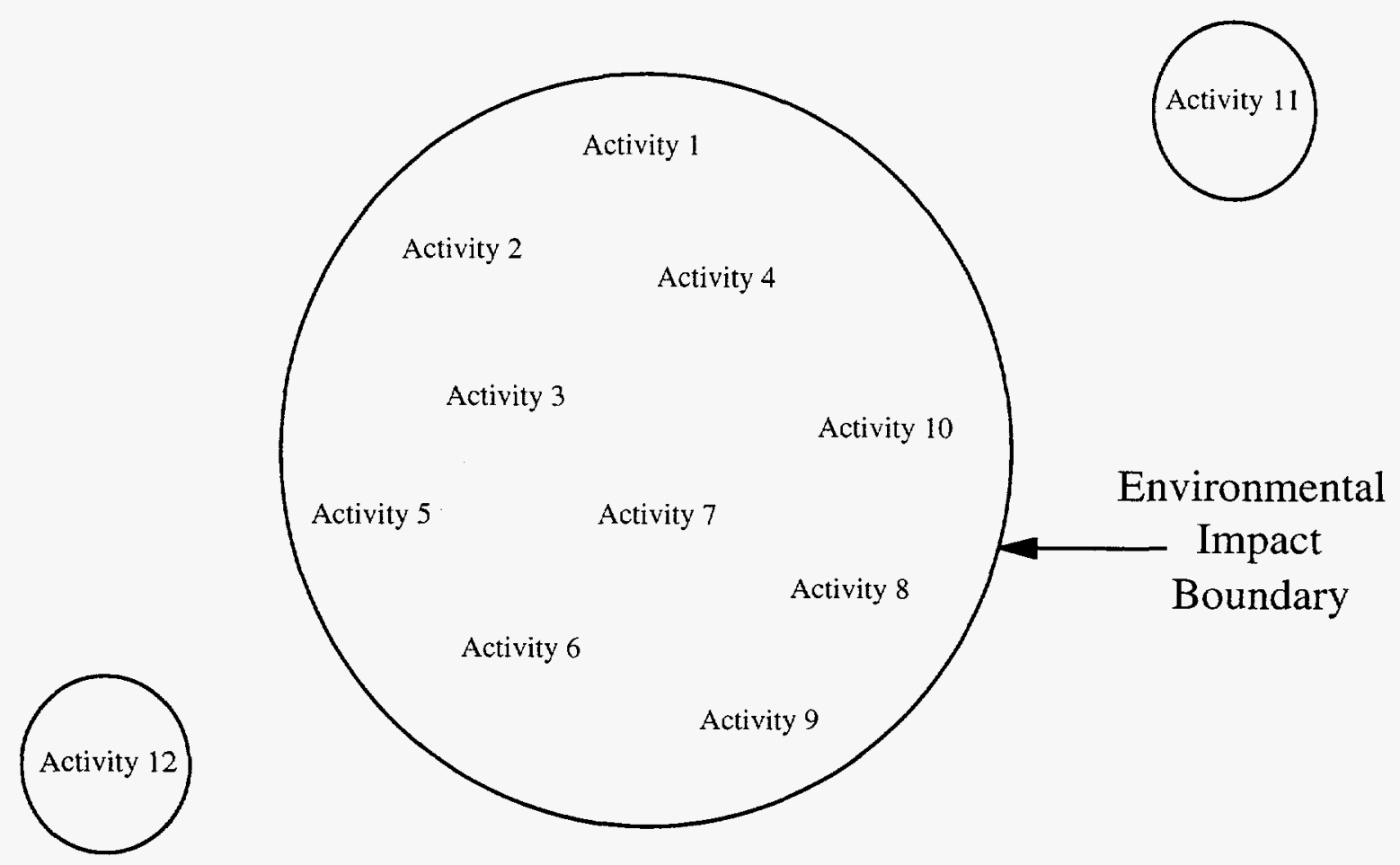

Note: Each "Activity" is part of an overall action. Activities 11 and 12 are not bounded by the EA or EIS and require separate NEPA documentation or a Supplemental EIS. See Wolff and Hansen 1994.

Figure 4. "Bounding" Environmental Impacts 
Implementing this approach will require that any line organization responsible for preparation of a NEPA document first conduct a search of previous NEPA documentation involving the same subject matter, including environmental baseline information. This approach will avoid timeconsuming and costly repetition of effort. It also identifies the need for a comprehensive, easily accessible and searchable library of Sandia NEPA documents

\subsection{Element 5: Prepare and Update Environmental "Baseline" Information}

Need: "Baseline" environmental information documentation is needed for both day-to-day NEPA compliance and to support the site-wide environmental impact statement (SWEIS). The existence of up-to-date environmental baseline information can significantly decrease the cost and time associated with preparation of NEPA documents.

Background: An "environmental baseline" refers to the existing physical, biological, and socioeconomic environment before it is altered (beneficially or adversely) by the program or project being proposed by a federal agency. The baseline should consist of data on a wide diversity of parameters (e.g., air and water quality, hydrology, meteorology, cultural resources, sensitive species, and socioeconomics). The presentation of these data in the "affected environment" sections of an EA or EIS can be tailored to focus on "significant" environmental issues. Standardizing this information and focusing it on relevant issues helps eliminate insignificant or unnecessary detail. It also avoids reinventing the environmental baseline description for each NEPA document.

SNL/NM initially published a comprehensive environmental baseline report in 1993 (IT Corporation and Consensus Planning, Inc./Zephyr Design, 1993). The document was extensively revised and updated in 1996 (IT Corporation, 1996). It was intended as a "living document" that would be updated periodically to reflect the current status of SNL/NM's environmental conditions. SNL/NM also prepared baseline reports to support specific assessment activities (Matise et al. 1994; Gutman; Silver 1994).

The SNL/NM Environmental Information Document (EID) was prepared in 1997 to support the SNL/NM site-wide EIS and other NEPA documents (Sandia National Laboratories, 1997a). Although it builds on the prior baseline documents, it contains much more information than was previously published. This information was drawn primarily from existing SNL/NM reports and databases. The SNL/NM EID represents one of a 3-volume set of information documents. The other two volumes include: the SNL/NM Program Information Document (Sandia National 
Laboratories, 1997b), which provides an overview of SNL/NM's ongoing and planned programs and activities; and the SNL/NM Facilities and Safety Information Document (Sandia National Laboratories, 1997c), which contains information on specific facility attributes and environmental, safety, and health aspects of SNL/NM operations.

The SNL/NM EID and other SNL/NM environmental baseline documents provide information on the following topics:

- Geology

- Land use

- Hydrology and water resources

- Air quality and meteorology

- Ecology

- Noise and vibration

- Cultural resources

- Visual resources

- Socioeconomics and community services

- Transportation

- Material management

- Waste management

- Regulatory requirements

Suggested Approach: Annually, review SNL/NM baseline information, and, as needed, update, expand and publish new and revised baseline documents. 


\subsection{Element 6: Support Earlier and More Comprehensive Internal DOE and SNLNM Scoping of NEPA Documents}

Need: Often, EAs and EISs are not adequately scoped internally before public scoping begins, document preparation commences, or a contractor is selected to assist in writing the EA or EIS. Sometimes this is unavoidable because the level of NEPA documentation required is determined at the last minute, allowing little time for scoping before document preparation begins.

Background: Requirements for public scoping are addressed in both the CEQ regulations ( $\$ 1501.7)$ and the DOE NEPA procedures (\$1021.311). However, there are no requirements for internal agency scoping which would logically proceed public scoping. This can result in a public scoping process fraught with surprise issues not anticipated by DOE and its contractors. While SNL/NM has not been given many EIS public scoping responsibilities in the past, this could change in the future.

Suggested Approach: Whenever possible, EAs and EISs should be thoroughly scoped by SNL/NM working in concert with the DOE-Kirtland Area Office (KAO). When an EIS is required, it is essential that comprehensive internal scoping precede any public scoping meetings. The best preparation for public scoping for an EIS (or EA preparation when public scoping is not involved) is a thorough, comprehensive internal scoping process. Scoping may be thought of as a process. Scoping should start as early as possible and should be designed for each project. Time spent for internal scoping will help avoid time-consuming delays later on in the NEPA process. Scoping may continue through the issuance of the draft EIS.

The scoping process is critical to separating significant issues to be analyzed in depth and issues that are either insignificant or that have been covered in previous NEPA documents. DOE refers to analysis of issues and impacts in proportion to their significance as a "sliding scale" approach. Scoping is needed for a sliding scale approach, which may also be thought of as separating the wheat from the chaff. Scoping is also a useful tool for discovering alternatives to proposals and mitigation measures that might render an otherwise environmentally significant action insignificant. A good starting point in preparing for scoping is to review the excellent Scoping Guidance prepared by the CEQ in $1981 .{ }^{12}$ As part of its oversight for implementing NEPA, the CEQ investigated agency and public experience with scoping. The CEQ

\footnotetext{
${ }^{12} 46$ Fed Reg. 88, May 7, 1981
} 
scoping guidance summarizes a series of recommendations that resulted from this research and contains step-by-step advice for government agencies and public participants. Although scoping can not be reduced to "a simple formula or cookbook," excellent guidance is available and courses on scoping are periodically provided by contractors and professional organizations such as the National Association of Environmental Professionals.

\subsection{Element 7: Support Efficient and Effective Public Scoping of EISs That Minimizes Confrontation}

Need: Although SNL/NM has been only minimally involved in public scoping in the past, the need for greater involvement may arise in the future (e.g., for supplements to the SWEIS or future EISs). SNL/NM should develop public scoping tools and techniques to support DOE efforts.

Background: The basic requirements for public scoping are spelled out in the CEQ regulations and DOE NEPA procedures referenced in strategy element 6 above. However, the regulations do not provide a methodology for conducting public scoping. The result is that many public scoping processes (particularly scoping meetings) become exercises in dissension, misunderstandings, and confrontation.

Suggested Approach: There are many tools and techniques that can be used in the public scoping process. An enumeration and detailed discussion of each of them is beyond the scope of this report. Public involvement specialists use many techniques including public meetings, participatory workshops, citizen advisory committees, public opinion surveys, and combinations of these and other methods. Generally, the least desirable public scoping process is the one most often used by various agencies: public meetings or hearings that are conducted with each "side" working against each other as adversaries. SNL/NM should take the initiative to develop and implement (when requested by DOE) innovative and productive public scoping tools and techniques. The effectiveness of these tools could be tested in internal "dry runs."

\subsection{Element 8: Prepare Detailed Annotated Outlines for Future EAs and EISs}

Need: Detailed annotated outlines are needed to serve as a "blueprint" or "road map" for the preparation of each EA or EIS. Each author needs specific guidance for the preparation of his or her section(s) of the document in order to avoid the necessity of writing numerous iterations. 
There is also a need for each author to have an overview of the entire EA or EIS, not just particular sections.

Background: Neither DOE nor CEQ requires the preparation of any type of outline for NEPA documents although CEQ recommends a "format" in $\$ 1502.10$. However, the CEQ regulations in $\$ 1500.4$ require that document authors "reduce excessive paperwork," reduce the length of NEPA documents, prepare documents that are "analytic rather than encyclopedic," write documents in "plain language," and follow a "clear format." Preparation of an annotated outline before any author starts writing could assist measurably in meeting these goals.

Annotated outlines have been prepared for a number of SNL/NM documents including: the KTF $E A$; the Integrated Materials Research Laboratory (IMRL) EA; the Environmental Restoration (ER) EA; the NEPA Compliance Guide; and several of the SWEIS EID document chapters. These outlines are much more than the standard table of contents in that they provide detailed guidance on how each section of the document is to be prepared and identify the data gaps. The annotated outlines generally have four parts (or columns if in tabular form): (1) outline element; (2) target number of pages for each element; (3) persons responsible for each element; and (4) annotations on how each element should be prepared.

Suggested Approach: SNL/NM NEPA practitioners, project managers, line managers, and others responsible for NEPA document preparation should ensure that an annotated outline is prepared for each and every EA or EIS and provided to each author before actual document preparation begins. Ideally, preparation of the annotated outline is an iterative process involving input from each author and reviewer.

\subsection{Element 9: Support Increased Integration of DOE and Air Force NEPA Compliance Requirements}

Need: SNL/NM NEPA practitioners need to champion the issue of NEPA reciprocity between DOE-KAO and Kirtland Air Force Base (KAFB).

Background: Much duplication of effort takes place when SNL/NM must meet both DOE and KAFB NEPA requirements. This results in unnecessary paperwork and expenditures of time and funds. 
Suggested Approach: Explore development of an electronic computer tool similar to ECL/ADM HELP for preparation of the U.S. Air Force (USAF) NEPA form (Form 813). Prepare a "white paper" on ideas and approaches for integrating the DOE NEPA process with the Air Force NEPA process. Over time, thousands of dollars might be saved by integrating the two processes, In addition, NEPA professionals would have additional time for more meaningful work.

Section 6.0 briefly discusses the USAF NEPA review process.

\subsection{Element 10: Improve NEPA Compliance and Documentation Records Management}

Need: SNL NEPA records should be maintained in centralized and satellite records centers. Information on NEPA records should be made available to line organizations through the use of electronic computer tools. Also, an "administrative record" should be maintained for use by legal counsel.

Background: The information services support of the SNL/NM site-wide EIS (SWEIS) consists of two operations that interact on a daily basis and mesh together to provide a complete information picture: (1) ES\&H Reference Services; and (2) records management.

Both of these operations deal with information and there is a small amount of duplication between them. However, a "record" is an information product produced by SNL that is strictly defined by 36 CFR $\S 1220.14$. Records are usually the original version or one-of-a-kind. In contrast, library or "reference" material includes information products that have been published and are available in duplicate copies through government or commercial publishing and distribution agents.

A centralized record keeping system for the SWEIS project has been established, including approved records filters. The records are housed in the ES\&H Records Center, Building 869, are indexed in an Oracle database, and are managed under a work agreement between the ES\&H Center and the Recorded Information Management Department.

Suggested Approach: NEPA practitioners should continue building files for all NEPA documents, available both electronically and in hard copy. Such a records system will be 
invaluable in implementing tiering, answering Freedom of Information Act and other legal requirements. A systematic NEPA planning record would also make it possible to create new documents based on precedents from previous experience.

\subsection{Element 11: Prepare Shorter and More Readable NEPA Documents}

Need: Contrary to the CEQ requirements discussed in strategy element 8 above, NEPA documents are too long, detailed, encyclopedic, and technical to be understood by the public. NEPA document authors predominately write for their peers in the same disciplines, not for public reviewers. Although this has been a problem since 1970, some agencies (including DOE) have made at least nominal progress in attacking the problem. There is a serious need for SNL/NM NEPA document managers, line managers, and others to focus at least as much attention on the organization and writing of NEPA documents as on their technical content.

Background: The CEQ requirements (not intended as an option) to write shorter documents in plain language that are analytic rather than encyclopedic are referenced in strategy element 8 above. Some elements of DOE's system have been working to implement these goals. For example, a recent Idaho National Engineering and Environmental Laboratory (INEEL) request for proposal (RFP) to prepare an EIS required that the selected contractor write a document not to exceed 150 pages (although nothing was said about appendices). The CEQ regulations in $\S 1502.7$ specify that the text of an EIS "normally" be less than 150 pages although documents of "unusual scope or complexity" may be "less than 300 pages."

Suggested Approach: SNL/NM line managers, project managers, and NEPA professionals should focus much more on NEPA document writing and organization than in the past. Past emphasis has been almost exclusively on technical and scientific content and not on manner of presentation of information. All NEPA training workshops and seminars should include a session on how to prepare shorter, more readable documents. Although technical editors should be involved in these training sessions, responsibility for writing clear, understandable documents should not be "delegated" to technical editors. Primary authors have this responsibility. Some specific suggestions are:

- Authors should write for agency and public reviewers who are not experts in a particular discipline. They should not write only for their peers. 
- Authors should avoid including encyclopedic detail in any topic but particularly topics like descriptions of the affected environment and risk assessment.

- Authors should use and refer regularly to the annotated outline prepared for an EA or an EIS.

- Document reviewers should refrain from suggesting or insisting on the inclusion of additional technical detail that only detracts from public understanding.

- SNL/NM recognition should be considered for in-house document preparers and contractors who prepare succinct and understandable documents that meet CEQ and DOE objectives and that are technically and scientifically credible.

- Page limits should be established-and adhered to as much as possible-for each EA and EIS.

Additional discussion of the strategy for streamlining the NEPA process is contained in the proceedings of the $23^{\text {rd }}$ Annual Conference of the National Association of Environmental Professionals (Hansen and Wolff, 1998). 


\title{
5. THE SITE-WIDE ANALYSIS APPROACH TO NEPA COMPLIANCE
}

This section discusses the CEQ requirements as a basis for the "site-wide" approach to preparing NEPA documents. It also provides the regulatory background for the DOE site-wide NEPA review process as well as two examples of site-wide analysis.

\subsection{CEQ Requirements}

The regulatory bases for preparing broad-scoped or "site-wide" NEPA documents is provided in the CEQ NEPA regulations at $\S 1502.4(a)$ as follows:

\begin{abstract}
"Agencies shall make sure the proposal which is the subject of an environmental impact statement is properly defined. Agencies shall use the criteria for scope $(\$ 1508.25)$ to determine which proposal(s) shall be the subject of a particular statement. Proposals or parts of proposals which are related to each other closely enough to be, in effect, a single course of action shall be evaluated in a single impact statement."
\end{abstract}

Although the regulations address environmental impact statements (EISs), the same logic applies to environmental assessments (EAs) which are really "mini EISs."

The CEQ regulations also deal with the closely related issue of segmentation. Segmentation occurs when the CEQ requirements pertaining to scope of a NEPA document are violated. The regulations in 40 CFR $\$ 1508.25$ require that EISs (and, by extension, other NEPA documents) consider three types of actions: (1) connected actions (e.g., those that are interdependent parts of a larger action or automatically "trigger" other actions.; (2) cumulatively significant actions (with cumulative impacts); and (3) similar actions (such as common timing or geography). Improper segmentation, for example, has appeared in a number of highway construction court cases where the Federal Highway Administration (FHA) has attempted to prepare narrow-scope EISs or EAs on small segments of major highways in order to minimize cumulative effects and avoid the responsibility of preparing comprehensive NEPA documents.

Segmentation is not always avoidable. For example, it may be impractical to address all of the phases of a long-term, multiphase project in one comprehensive NEPA document when the timing, technology, and even the funding for later phases are uncertain or speculative. 
In preparing EISs, such as site-wide statements, one should be sensitive to potential conflicts of interest. The CEQ regulations and guidance on conflict of interest as well as leading federal court opinions were reviewed by Hansen and Wolff 1997.

\subsection{The DOE Site-wide NEPA Review Process}

The April 1992 DOE NEPA implementing procedures [10 CFR $§ 1021.330(\mathrm{c})$ ] establish the requirements for programmatic (including site-wide) EAs or EISs. The regulations provide:

"As a matter of policy when not otherwise required, DOE shall prepare site-wide EISs for certain large, multiple-facility DOE sites; DOE may prepare EISs or EAs for other sites to assess the impacts of all or selected functions at those sites."

DOE considers site-wide NEPA documents to be "programmatic" in nature and particularly applicable to sites containing facilities that support "diverse and unrelated missions and activities" (57 FR at 15128, April 24, 1992). Site-wide documents are envisioned by DOE as performing a review of the "collective potential of environmental effects... on a single geographic location, and... operated under a single management...A site-wide NEPA review evaluates the potential individual and cumulative environmental impacts of ongoing and reasonably foreseeable activities at a DOE site..." (57 FR 15128). As a large, multiple-facility site situated at a single geographic location, carrying out diverse activities and functioning under a single management, SNL/NM meets all DOE criteria for the site-wide EIS (SWEIS) currently being prepared.

DOE's Secretarial Policy on the National Environmental Policy Act of June 1994 requires that field organizations (e.g., DOE-Albuquerque Operations Office [AL]) include in an annual NEPA planning summary "an evaluation of whether a site-wide environmental impact statement would facilitate future NEPA compliance efforts" (U.S. Department of Energy, 1994a). On December 15, 1994, the DOE-Headquarters (HQ) Office of NEPA Oversight (now Office of NEPA Policy and Assistance, $\mathrm{EH}-42$ ) issued a memorandum on the benefits of site-wide NEPA review (EA or EIS) (U.S. Department of Energy; 1994b). According to the memo, a site-wide NEPA review will:

- Aid in meeting DOE's goal of "streamlining" the NEPA process and making it more useful for decision-makers and the public.

- Reduce time and cost required to prepare NEPA documents following site-wide NEPA review.

- Provide a "tiering" document for project-specific NEPA documents containing more detailed project-specific information. 
- Implement the most efficient and effective method of analyzing the cumulative impacts of past, present, and foreseeable future activities.

- Provide, in certain circumstances, a vehicle for assessing the impacts of multiple proposed projects in one document.

- Comply with CEQ (and DOE) regulatory requirements by avoiding segmentation (minimizing impact significance by dividing large actions into smaller actions) that may be subject to a court challenge.

- Facilitate comprehensive, responsible land use planning consistent with DOE's ecosystembased land and facility use policy.

- Support the Secretary of Energy's policy of increasing public participation in decision making.

- Provide an effective and efficient means of comprehensively responding to stakeholder concerns.

The SNL/NM SWEIS currently being prepared can potentially result in all of these benefits. Following are two examples of site-wide NEPA reviews. In addition, an umbrella NEPA review was also completed for SNL/NM Technical Area IV. (DOE 1996).

\subsubsection{Site-wide NEPA Review at the Kauai Test Facility (KTF)}

A paper entitled Use of Comprehensive NEPA Documents to Reduce Program Risk (Wolff and Hansen, 1994), which focuses on the Kauai Test Facility (KTF) EA (U.S. Department of Energy, 1992b), discusses three benefits of site-wide NEPA review: (1) integration in one document of other environmental regulatory compliance requirements; (2) reduction in project delays through simultaneous approval of ongoing and foreseeable actions; and (3) facilitation of the use of appropriate categorical exclusions (CXs).

Preparation of a comprehensive, programmatic-type NEPA document for a single facility like the KTF can reduce program risks and provide a competitive advantage over piecemeal, fragmented, segmented, and "one-project-at-a-time" approaches to NEPA compliance. Necessary activities can proceed expeditiously, unhampered by NEPA compliance crises, at a facility that has a document in place that bounds the impacts of both ongoing and foreseeable future actions.

Although federal agencies have adopted NEPA procedures, NEPA compliance is rarely endorsed enthusiastically by proponents of a proposed action when they perceive the procedural 
requirements as an impediment to their mission. Proponents may attempt to use the assessment process as a decision-implementation process rather then as a decision-making process. They may commence NEPA documentation late and then rush the preparation of assessments to meet impossible schedules. The site-wide NEPA review approach taken for the KTF EA eliminated a last minute rush to complete NEPA documents and provided a recognized value to the proponents of the action by positioning then to take on work for others and thus satisfy customer requirements. The site-wide approach pioneer at the KTF has influenced DOD EIS preparation at other rocket launching facilities

\subsubsection{Site-wide NEPA Review for the Environmental Restoration (ER) Project}

Strategies for integration of NEPA and the Resource Conservation and Recovery Act (RCRA) and other special integration issues for the Environmental Restoration (ER) Project were detailed in SAND92-7312, NEPA/CERCLAVRCRA Integration Strategy for Environmental Restoration Program: Sandia National Laboratories, Albuquerque (Hansen, 1992), that was prepared under the direction of the NEPA Team prior to efforts to initiate a site-wide ER EA. The integration strategy was also discussed in. "NEPA/CERCLA/RCRA Integration: Policy Vs Practice" in Proceedings of the 1993 Conference of the National Association of Environmental Professionals, Current and Future Priorities for Environmental Management (Hansen and Wolff, 1993).

EA preparation for the ER Project (U.S. Department of Energy, 1995) stemmed a prior flood of environmental checklist/action description memorandum (ECL/ADM) reviews of ER actions. Checklists solved the immediate problem for one small project at a time. However, they did not result in efficient use of resources in the long term. In fact, processing numerous checklists for closely related actions delayed the completion of the ER EA.

The completed programmatic ER EA helped avoid unnecessary segmentation. Also, the ER sitewide EA benefited the ER Project in several ways:

- Fulfilled the CEQ requirement for "early" consideration of environmental values.

- Integrated regulatory compliance in numerous environmental areas.

- Reduced paper flow through DOE by facilitating DOE NEPA approval at one time for numerous ongoing and foreseeable future actions.

- Facilitated the use of categorical exclusions (CXs), reducing the need for numerous EAs and possibly EISs at the RCRA Facility Investigation/Corrective Measures (RFI/CMS) study level. 
- Allowed any necessary site-specific NEPA documentation to be "tiered" from a comprehensive site-wide EA.

- Presented cumulative impact information so that the decision makers and the public had a better understanding of the totality of environmental impact from past, present, and reasonably foreseeable activities at SNL/NM.

- Supported DOE public participation policies including the provision of public participation opportunities. 


\section{INTEGRATION OF NEPA COMPLIANCE WITH OTHER ENVIRONMENTAL LAWS AND REVIEW PROCESSES}

This section discusses the opportunity that the NEPA process presents for responding to other environmental compliance requirements while preparing an EA or EIS. Integrating NEPA documents with Air Force, biological review, and cultural resources review processes are discussed as examples.

\subsection{Integration of NEPA Compliance With Other Environmental Laws}

The CEQ regulations require federal agencies to:

"Integrate the requirements of NEPA with other planning and environmental review procedures required by law or by agency practice so that all such procedures run concurrently rather than consecutively. [40 CFR $\$ 1500.2(c)] "$

More specifically, the CEQ requires in $\S 1502.25$ (a) that agencies integrate environmental impact analyses with related "surveys and studies" required by the Fish and Wildlife Coordination Act (16 U.S.C. $\$ 661$ et seq.), the National Historic Preservation Act (NHPA), 16 U.S.C. $\$ 470$ et seq., and the Endangered Species Act (ESA), 16 U.S.C. $\$ 1531$ et seq. Further, a draft environmental impact statement (DEIS) must list all federal "permits, licenses, and other entitlements" which are needed to implement the proposed action [\$1502.25(b)]

Compliance with other environmental laws (federal, state, and local) and integration of NEPA documentation with other environmental review requirements accomplishes multiple purposes including:

- Helps fulfill the broad environmental protection policy objectives enumerated in NEPA §101(b).

- Indicates the nature and magnitude (significance) of possible environmental consequences of the proposed action.

- Saves time, resources, and paperwork by consolidating environmental compliance measures in a single document.

Addressing multiple environmental compliance requirements in a NEPA document helps an agency carry out policy mandates contained in NEPA $\$ 101(b)$, which are often ignored in the NEPA process. Many major SNL/NM or DOE activity requires compliance with multiple 
requirements, such as the Clean Air Act (CAA), Clean Water Act (CWA), Resource Conservation and Recovery Act (RCRA), Comprehensive Environmental Response, Compensation and Liability Act (CERCLA), Safe Drinking Water Act (SDWA), National Historic Preservation Act (NHPA), Endangered Species Act (ESA), and their New Mexico or local counterparts. Compliance with these and many other requirements helps DOE meet NEPA objectives such as those listed in Section 1.1 of this report.

If a permit, license, certification, or other form of agency approval or authorization is required for a certain type of air emission, water discharge, land disturbance, habitat disruption, or other activity associated with a proposal, it is a good indication of the type and degree of potential impact that a NEPA document must address. At the same time, implementing another environmental law (e.g., hazardous waste cleanup required by CERCLA and/or RCRA) may itself create impacts that must be included in a NEPA analysis.

Further, compliance with other environmental laws serves as a method of preventing what might otherwise be unacceptable environmental consequences (e.g., contributing to significant deterioration of air quality or destroying archaeological resources). It is usually appropriate in NEPA documents to include a discussion of compliance with other regulatory requirements in the context of identifying specific mitigation measures. However, compliance with other environmental laws should not lead to an assumption that there are no adverse impacts or that the impact is acceptable.

Coordination of NEPA documentation requirements with the documentation requirements of other laws and regulations whenever possible will help avoid delays and needless duplication of effort. Handled judiciously, such integration can result in significant savings of time and resources. Document integration, however, may not always be feasible or practical. For example, the Secretarial Policy on the National Environmental Policy Act (June 1994) calls for "streamlining" the NEPA process by incorporating NEPA values (such as the analysis of cumulative, offsite, ecological, and socioeconomic impacts) into Comprehensive Environmental Response, Compensation, and Liability Act (CERCLA) documents to the extent practicable in order to avoid unnecessary delays and minimize costs. Attempting to make a NEPA document serve a "one-stop shopping" compliance purpose can result in documents that are too lengthy, too encyclopedic, and confusing to regulators and the public. 


\subsection{Integration of NEPA Compliance With Other Review Processes}

At the facilities where DOE is a tenant or permittee of another federal agency, the NEPA compliance procedures of that particular federal agency must be considered. This section briefly discusses the U.S. Air Force (USAF) NEPA process.

\subsubsection{U.S. Air Force (USAF) NEPA Process}

The USAF has its own environmental impact analysis process (EIAP) that is a step-by-step method for analyzing USAF proposed actions and their alternatives and determining their effect on the environment. Because actions at Sandia National Laboratories (SNL) often involve USAFowned or permitted lands, the USAF NEPA process often needs to be complied with in addition to any required DOE NEPA compliance.

The USAF NEPA process is initiated using USAF Form 813. The process starts with a Description of the Proposed Action and Alternatives (DOPAA). NEPA practitioners at SNL/NM must be knowledgeable of both the USAF and DOE NEPA implementing procedures. Because several federal agencies are located at the Kirtland Federal Complex (KFC) ${ }^{13}$, land ownership and use is complicated. Consequently, NEPA compliance may require considerable coordination. Although the Air Force like the DOE must comply fully with the CEQ regulations, the two Federal Agencies have their own implementing regulations. At present, the Air Force NEPA implementing regulations are rapidly changing just as the DOE NEPA implementing regulations underwent much change a few years ago.

The USAF NEPA process generally applies to any action on Kirtland Air Force Base (KAFB) land involving use permit applications for new land leases, use permit renewals, and actions not described in the current use permit which may require amendment of the permit.

USAF NEPA compliance is generally required for the following:

- Requests for a land use permit on USAF property

- Request for renewals of land use permits on USAF property

\footnotetext{
${ }^{13}$ SNL/NM is located within the KFC. The KFC contains the federal entities located approximately within the geographic confines of KAFB. DOE lands and facilities, USAF lands and facilities, U. S. Forest Service (USFS) lands, and Bureau of Land Management (BLM) lands withdrawn from public use are all contained within the KFC. Sandia's activities occur on all of these lands.
} 
- Amendment of existing permits for reasons including, but not limited to, changes in land use, actions not covered in existing permit conditions, increase of hazards related to operations conducted under the existing permit, addition of structures, or change in the size of the leased parcel.

The USAF conducts its NEPA review activities pursuant to "Air Force Instruction." The instruction is by order of the Secretary of the USAF and describes specific tasks and procedures for the USAF EIAP.

In January 1995, KAFB issued The Environmental Impact Analysis Process Guide (Shipley Associates, 1995) to implement NEPA compliance procedures contained in Air Force Instruction (AFI) 32-7061 of March 7, 1994 entitled The Environmental Impact Analysis Process (EIAP) (U.S. Air Force, 1994). Among other things, the EIAP provides detailed instructions for filling out AF Form 813, which must be submitted to the KAFB Technical Advisory Subcommittee (TAS). The TAS then makes a determination on the required level of NEPA documentation for a proposed action (categorical exclusion [CX], environmental assessment [EA], or environmental impact statement [EIS]).

\subsubsection{Biological Review Process}

Attachment $V$ of SNL's NEPA Compliance Guide (Hansen, 1995) discusses the responsibilities of federal agencies with respect to biological review processes. The Endangered Species Act (ESA), 16 U.S.C. $\$ 1531$ et seq., applies to both private individuals and government agencies. Section 9 of the Act makes it illegal for any person to "take" any endangered species of fish or wildlife. "Take" means to harass, harm, pursue, shoot, hurt, kill, capture, or collect, and includes interfering with habitat.

The earliest published biological survey for SNL/NM was done by Martin and Wagner 1974. This survey contained a species inventory checklist and was completed in support of the 1977 sitewide Environmental Impact Assessment (EIA) (ERDA 1977). A revised species inventory was prepared by Fischer 1990. Later surveys were completed in support of specific proposed actions. These are the published work of Sullivan and Knight 1994 and Sullivan 1994.

Under Section 7 of the ESA, DOE must follow one of several steps in the compliance and consultation process known as the "Section 7 consultation process." Section 7 applies only to federal agencies which must ensure that any action authorized, funded, or carried out by them 
will not jeopardize the continued existence of a threatened or endangered (T/E) species or result in adverse modifications of its habitat.

Section 7 of the Act requires a federal agency to:

- Obtain a scientific permit for capturing, killing, monitoring, or performing scientific studies involving T/E wildlife and plant species.

- Confer with the U.S. Fish and Wildlife Service (USFWS) regarding listed or proposed species or critical habitat.

- Prepare a biological assessment of the proposed action, if necessary.

- Perform "formal consultation" with the USFWS on potential impacts to species or habitat, if necessary.

Prior to beginning construction or ground-disturbing activities, SNL/NM representatives (with DOE approval) should confer with the USFWS; the New Mexico Department of Game and Fish (NMDGF); and/or the New Mexico Energy, Minerals, and Natural Resources Department with respect to these or any other species that are suspected to be present at the project location. Before beginning construction or ground-disturbing activities on U.S. Forest Service (USFS) withdrawn lands, SNL/NM needs to confer with the USFS. The USFS assumes the responsibility for species surveys and consultation with the agencies on withdrawn lands.

If DOE or SNL/NM determines that a potential presence of a listed or proposed species or habitat exists within the project area, a biological assessment must be prepared. The assessment will address how the project "may affect" proposed or listed endangered species, threatened species, or critical habitat. If an adverse effect on these species or habitat is anticipated, formal consultation can be requested by DOE or USFWS. The formal consultation will result in a written biological opinion containing a "jeopardy" or "no-jeopardy" decision by the USFWS regarding the fate of endangered species within the project area or within other affected areas. It is generally advisable to include documentation regarding compliance with the Section 7 process (e.g., correspondence with the USFWS and/or the NMDGF) in an EA or EIS.

The NMDGF also has procedures that DOE must follow in order to comply with federal and state regulations concerning T/E species. When DOE or SNL/NM anticipates an action that might affect endangered species in New Mexico, the NMDGF must be contacted. The department will provide the current state list of endangered species in New Mexico, a handbook of endangered species, 
and the state requirements for compliance with the New Mexico Wildife Conservation Act. The Act gives jurisdiction to the department over all indigenous, non-domestic vertebrate species (i.e., amphibians, birds, fish, mammals, reptiles) as well as crustaceans and mollusks.

Using the material provided by the NMDGF Endangered Species Program and/or field studies, SNL/NM must determine the species that might be affected within the proposed project area. A list of endangered animal and plant species must be developed and the potential impacts assessed. The assessment can lead to one of three results:

- No endangered species are present and there are no impacts resulting from the proposed action.

- Endangered species are present but the proposed project will not have an impact on the species.

- Endangered species are present and there are projected impacts to the species.

SNL/NM must submit the assessment to the NMDGF for review. SNL/NM must seek consultation with the NMDGF concerning steps to avoid or mitigate known adverse effects to endangered species. The New Mexico Department of Energy, Minerals, and Natural Resources uses the same criteria and procedures to protect endangered plant species within the state. (\$75-6-1 NMSA 1978).

\subsubsection{Cultural Resource Review Process}

Attachment IV of SNL's NEPA Compliance Guide provides procedures and consultations related to compliance with cultural resources protection requirements (Hansen, 1995). A cultural resources overview for SNL/NM was prepared in 1993 by Hoagland.

This section discusses the major federal statutes pertaining to archaeological and historic preservation. 


\subsubsection{National Historic Preservation Act (NHPA)}

The National Historic Preservation Act (NHPA) (16 U.S.C. $\$ 470$ et seq.) was enacted to protect the nation's cultural resources. The NHPA established the Advisory Council on Historic Preservation (ACHP), the state historic preservation officers (SHPOs), and the National Register of Historic Places (NRHP). Section 106 directs federal agencies to take into account the effects of their actions on properties included on or eligible for the NRHP. Under Section 110(a) and Executive Order (E.O.) 11593, federal agencies are required to locate, inventory, and nominate all properties under their control that may qualify for inclusion in the NRHP. Section $110(f)$ requires specific planning and actions to minimize harm to any national historic landmark that may be adversely affected by a federal agency's actions.

The Section 106 process involves five steps that SNL/NM, working with DOE, must follow:

- Identification of the historic properties within the area of a proposed action. ${ }^{14}$

- Determination of the effects of a proposed project on archaeological and historic properties.

- Early consultation among DOE, the SHPO, and others to seek ways to avoid or reduce the effects on cultural resources.

- Affording the ACHP a reasonable opportunity to comment on the undertaking.

- Proceeding with the agency's decision-making process

The NHPA was amended in 1992. The primary effect of the amendments was to pass the authority for consultation activities from the ACHP to the SHPO. In addition, the amendments give Indian tribes the authority to act as the SHPO on Indian lands.

\subsubsection{Archaeological and Historic Preservation Act (AHPA)}

The NHPA has been amended by the Archaeological and Historic Preservation Act (AHPA) of 1974. The AHPA directs federal agencies to recover and preserve historic and archaeological data that would otherwise be lost as a result of federal construction, activities, or programs affecting cultural resources.

\footnotetext{
14 This step may include a literature/records search and a pedestrian cultural resources survey.
} 


\subsubsection{Archaeological Resources Protection Act (ARPA)}

The Archaeological Resources Protection Act (ARPA) requires a permit from the U.S. Department of the Interior for excavation or removal of archaeological resources from public or Indian lands. The Act establishes criminal and civil penalties for the illegal excavation, removal, damage, sale, purchase, or exchange of archaeological items. Any excavations conducted on, or removal of archaeological resources from, SNL/NM lands require an ARPA permit obtained through the National Park Service.

\subsubsection{Protection of Historic and Cultural Properties (36 CFR Part 800)}

These regulations implement the NHPA, specifically defining the process used by a federal agency (DOE) to meet the responsibility of taking into account the effects of its actions on cultural resources. These regulations:

- Describe in detail the five $\$ 106$ consultation processes delineated in section 6.2 .3 above.

- Establish roles for the SHPO, the ACHP, applicants for federal permits and licenses, local governments, and Indian tribes.

- Establish criteria for determining the cultural effects on a proposed action.

Other regulations pertaining to historic preservation include:

- 36 CFR Part 60, National Register of Historic Places.

- 36 CFR Part 62, National Register of Natural Landmarks.

- 36 CFR Part 63, Determinations of Eligibility for Inclusion in the National Register of Historic Places.

- 36 CFR Part 65, National Historic Landmarks Program. 


\subsubsection{American Indian Religious Freedom Act (AIRFA)}

The American Indian Religious Freedom Act (AIRFA), 42 U.S.C. $\$ 1996$ et seq., establishes a national policy to protect and preserve the right of Native Americans (American Indians, Eskimos, Aleuts, and Native Hawaiians) to believe, express, and exercise their traditional religious and ceremonial rites. Consultation with potentially affected Native Americans (e.g., the Isleta Pueblo) by either DOE or the USAF is necessary if infringement on religious rites or ceremonial sites by a proposed action is likely.

\subsubsection{Native American Graves Protection and Repatriation Act (NAGPRA)}

The Native American Graves Protection and Repatriation Act (NAGPRA) (25 U.S.C. $\$ 3001$ et seq.) provides for the protection of Native American graves, human remains, and funerary objects. Intentional excavation and removal of Native American human remains and objects from tribal or federal lands can be conducted only after consultation with the appropriate Indian tribe. In the event of inadvertent discovery of Native American remains and objects (e.g., during construction) on federal or tribal lands, the federal agency having management authority over the federal lands (Interior, Agriculture, or Energy in the case of SNL/NM) must be notified in writing. Activity in the area of the discovery must cease and a reasonable effort must be made to protect the items discovered before activity is resumed. Following notification of the appropriate agency (or tribal organization for tribal lands), and upon certification from the secretary of the agency that notification has been received, activity in the area may resume 30 days after such certification.

\subsubsection{Protection and Enhancement of the Cultural Environment (E.O. 11593).}

This executive order (E.O.) directs federal agencies to: (1) administer the cultural properties under their control in a "spirit of stewardship and trusteeship for future generations"; (2) initiate measures to preserve, restore, and maintain federally owned sites, structures, and objects of historical, archaeological, or architectural significance; and (3) institute procedures to ensure that federal programs contribute to the preservation of non-federally owned sites, structures, and objects of historical, architectural, or archaeological significance. DOE is required to initiate procedures to preserve cultural resources recorded on DOE and SNL/NM lands. 


\subsubsection{State of New Mexico Role}

New Mexico has an active cultural resources protection program administered by the New Mexico Historic Preservation Division, Office of Cultural Affairs under the Cultural Properties Act (§ 18-6-1 et seq. NMSA 1978). The State Historic Preservation Officer (SHPO) plays a key role in the NHPA \$106 process. The Prehistoric and Historic Sites Preservation Act (\$18-8-8 NMSA 1978) facilitates the preservation of significant prehistoric and historic sites by authorizing partnerships between government and corporate entities.

The preservation procedures processes are discussed under 6.2.3 Protection of Historic and Cultural Properties (36 CFR Part 800).

Under the consultation process, federal agencies must preserve and protect historic and cultural properties. The "Section 106 process," must be followed whenever DOE proposed a project or an action that involves land surface or subsurface disturbance that would affect cultural resources. DOE is responsible for initiating consultation process with the SHPO. 


\section{NEPA TRAINING ACTIVITIES AND SNL/NM}

A number of training courses have been organized and presented at Sandia National Laboratories (SNL/NM). NEPA training is essential for both NEPA practitioners and line organizations that prepare or participate in the preparation of NEPA documents.

In the past, consultants conducted most of the training. In recent years, much of the NEPA training has been done internally.

Courses offered are (McAllaster, 1997):

- ENV120, NEPA Awareness.

- ENV121-1, Integrating NEPA into SNL Project Planning.

- ENV121-2, Managing the Preparation of the Environmental Assessment at SNL.

- ENV122, Applying the NEPA Process.

- ENV124, Writing Effective NEPA Documents.

In addition, seminars are organized for specialized topics on a case-by-case basis. 


\section{CONCLUSION}

SNL/NM has made considerable progress over the past several years in improving and streamlining the NEPA process. However, much remains to be accomplished in order to prepare higher quality documents and make the entire NEPA process work better and cost less.

As this report demonstrates, SNL/NM line managers, project managers, NEPA support personnel, and other NEPA professionals have made significant contributions to ensure that SNL/NM maintains its position of NEPA compliance leadership.

SNL/NM NEPA practitioners have provided invaluable assistance to line organizations over a period of many years. A number of publications prepared or sponsored by SNL/NM NEPA professionals and contractors (see Attachment III) have benefited not only Sandia Corporation but also DOE and the NEPA professional community at large.

Even with this successful track record, a number of steps need to be taken to ensure continuing improvement in NEPA compliance at SNL/NM and other SNL facilities. Section 4.0 discusses the eleven recommended improvement elements in detail. In order for NEPA compliance to function more efficiently and be more useful to DOE and SNL/NM decision-makers and the public, it is essential that these improvements be implemented within a reasonable time frame. The NEPA compliance effort must not be diminished or relaxed if potential legal vulnerability of DOE is to be minimized and emerging challenges are to be met.

Although not discussed in this report, a number of emerging issues will engage NEPA professionals in the near future. These include: (1) how deregulation could affect NEPA compliance if private consultants perform tasks currently performed by government agencies;

(2) the links being forged between impact assessment and International Organization for Standardization (ISO) $14000 ;{ }^{15}$ and (3) impact assessment for sustainable development decisionmaking.

\footnotetext{
${ }^{15}$ ISO 14000 is a global environmental standard and environmental management system that is being used by business to manage and control environmental risks. It was developed by the International Organization for Standardization (ISO). The U.S. is a member of ISO and is officially represented by the American National Standards Institute (ANSI).
} 


\section{REFERENCES}

Energy Research and Development Administration (ERDA), 1975, Environmental Assessment, EIA/MA/76-2, Tonopah Test Range, Tonopah, Nevada.

Energy Research and Development Administration (ERDA), 1975, Omnibus Environmental Assessment, SAND75-0268, Draft, Sandia National Laboratories, Livermore, California.

Energy Research and Development Administration (ERDA), 1977, Environmental Impact Assessment, EIA/MA 77-1, Sandia National Laboratories, Albuquerque, New Mexico.

Fischer, N. T, 1990, Revision of Species Inventory Checklists for Sandia National Laboratories, Albuquerque Bernalillo County, New Mexico, SAND90-7098, Sandia National Laboratories, Albuquerque, New Mexico.

Gutman, W. M., and R. J. Silver, 1994, Air Quality Investigations of the Sandia National Laboratories Sol se Mete Aerial Cable Facility, SAND 93-7094, Sandia National Laboratories, Albuquerque, New Mexico.

Hansen, R. P., T. A. Wolff, and L. N. McCold, 1997, "The Conflict of Interest Problem in EIS Preparation" in Proceedings of the 1997 Conference of the National Association of Environmental Professionals May 19-22, Orlando, Florida.

Hansen, R. P., 1992, NEPAVCERCLA/RCRA Integration Strategy for Environmental Restoration Program, Sandia National Laboratories, Albuquerque, SAND92-7312, Sandia National Laboratories, Albuquerque, New Mexico.

Hansen, R. P, 1995, National Environmental Policy Act (NEPA) Compliance Guide Sandia National Laboratories, SAND95-1648, Sandia National Laboratories, Albuquerque, New Mexico.

Hansen, R. P., and T. A. Wolff, 1993, "NEPACERCLA/RCRA Integration: Policy VS Practice" in Proceedings of the 1993 Conference of the National Association of Environmental Professionals, Current and Future Priorities for Environmental Management, May 24-26.

Hansen, R. P., and T. A Wolff, 1998. "Streamlining the Process: A Strategy for Making NEPA Work Better and Cost Less" in Proceedings of the 1998 Conference of the National Association of Environmental Professionals, Environmental Management: Linking NEPA, ISO 14000 and Sustainable Development June 20-26, San Diego, California.

Harris, J. M., 1995a, Annotated Bibliography of National Environmental Policy Act (NEPA) Documents for Sandia National Laboratories, SAND94-2032, Sandia National Laboratories, Albuquerque, New Mexico.

Harris, J. M., 1995b, "Integrating National Historic Preservation Act Compliance into the National Environmental Policy Act Process" in National Association of Environmental Professionals (NAEP) 20th Annual Conference Proceedings Environmental Challenges: The Next 20 Years June 10-14, 1995, Washington, D. C.

Harris, J. M., 1997, Chapter 13, Section A, NEPA, Sensitive Species, and Historic Properties, MN471001, ES\&H Manual, Issue D, Sandia National Laboratories, Albuquerque, New Mexico. 
Hoagland, S. R., and K. J. Lord, 1993, Cultural Resources Regulatory Analysis, Area Overview, and Assessment of Previous Department of Energy and Kirtland Air Force Base Inventories for Sandia National Laboratories, SAND92-7345, Sandia Laboratories, Albuquerque, New Mexico.

IT Corporation, 1996, Sandia National Laboratories/New Mexico Environmental Baseline Update-Revision 1.0, SAND96-1608, Sandia National Laboratories, Albuquerque, New Mexico.

Mandelker, D. R., 1997 NEPA Law and Litigation, \$1.01, Clark Boardman Callahan, New York, NY.

March, F., 1996, "Determining the Significance of Proposed Actions" in Proceedings of the 1996 National Association of Environmental Professionals (NAEP), Practical Environmental Directions: A Changing Agenda, June 2-6, 1996: Houston, Texas, June 2-6.

Martin, W. C., and W. L. Wagner, 1974, Biological Survey of Kirtland Air Force Base (East), SAND74-0393, Sandia National Laboratories, Albuquerque, New Mexico.

Matise, B. K., W. M. Gutman, R. A. Cuniff, R. J. Silver, and W. E. Stepp, 1994, Noise and Vibration Investigations of the Sandia National Laboratories Sol se Mete Aerial Cable Facility, SAND93-7095, Sandia National Laboratories, Albuquerque, New Mexico.

McAllaster, J., 1997, ES\&H Training Catalog, MN471010, Issue H, Sandia National Laboratories, Albuquerque, New Mexico.

National Environmental Policy Act of 1969I, 42 U.S.C. 4341 et seq.

Sandia National Laboratories, 1997a, SNLNM Environmental Information Document (EID), Preliminary Draft, Sandia National Laboratories, Albuquerque, New Mexico.

Sandia National Laboratories, 1997b, SNLNM Program Information Document, Preliminary Draft, Sandia National Laboratories, Albuquerque, New Mexico.

Sandia National Laboratories, 1997c, SNLNM Facilities and Safety Information Document, Preliminary Draft, Sandia National Laboratories, Albuquerque, New Mexico.

Sandia National Laboratories, 1998, ES\&H Manual, MN471001, Issue BU, Sandia National Laboratories, Albuquerque, New Mexico.

Shipley Associates, 1995, The Environmental Impact Analysis Process Guide, Kirtland Air Force Base.

Sullivan, R. M., and P. J. Knight, 1994, Biologic Surveys for the Sandia National Laboratories Coyote Canyon Test Complex Kirtland Air Force Base Albuquerque, New Mexico, SAND937089, Sandia National Laboratories, Albuquerque, New Mexico.

Sullivan, R. M., 1994, Biological Investigations of the Sandia National Laboratories Sol se Mete Aerial Cable Facility, SAND93-7093, Sandia National Laboratories, Albuquerque, New Mexico.

U.S. Air Force (USAF), 1994, The Environmental Impact Analysis Process (EIAP), AFI 32-7061.

U.S. Department of Defense (DoD), February 1998 Draft Environmental Impact Statement, Pacific Missile Range Facility Enhanced Capability, Pacific Missile Range Facility Kehaha, Hawaii. 
U.S. Department of Energy, 1992a, Final Environmental Impact Statement and Environmental Impact Report for Continued Operation of the Lawrence Livermore National Laboratory and Sandia National Laboratories, Livermore, DOE/EIS-0157, U.S. Department of Energy and University of California, Oakland California.

U. S. Department of Energy Albuquerque Operations Office (DOE/AL), July 1992b Kauai Test Facility (KTF) Environmental Assessment, DOE/ EA-0492, DOE Al, Albuquerque, NM.

U.S. Department of Energy, 1994a, Secretarial Policy on the National Environmental Policy Act, Washington, D.C.

U.S. Department of Energy, 1994b, Benefits of Site-wide National Environmental Policy Act (NEPA) Review, Washington, D.C

U.S. Department of Energy, 1996, Environmental Assessment for Operations, Upgrades, and Modifications in SNLINM Technical Area IV, DOE/EA-1140.

U.S. Department of Energy, 1996, Environmental Assessment for the Environmental Restoration Project at Sandia National Laboratories/NM, DOE/EA-1153.

Wolff, T. A., and R. P. Hansen, 1993, "The NEPA Threshold Question Revisited: Proposed Actions and Continuing Activities" in Proceedings of the 1993 Conference of the National Association of Environmental Professionals, Current and Future Priorities for Environmental Management, Raleigh, North Carolina.

Wolff, T. A., and R. P. Hansen, 1996, "Tools for NEPA Compliance: Baseline Reports and Compliance Guides" in Proceedings of the 1996 Conference of the National Association of Environmental Professionals, Practical Environmental Directions: A Changing Agenda, Houston, Texas, June 2-6.

Wolff, T. A., and R. P. Hansen, 1994, "Use of Comprehensive NEPA Documents to Reduce Program Risk" in Proceedings of the 1994 Conference of the National Association of Environmental Professionals, Global Strategies for Environmental Issues, New Orleans, Louisiana, June 12-15, 1994. 


\section{ATTACHMENT I}

\section{NEPA COMPLIANCE GUIDE TABLE OF CONTENTS}




\section{Table of Contents}

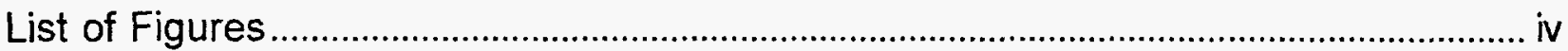

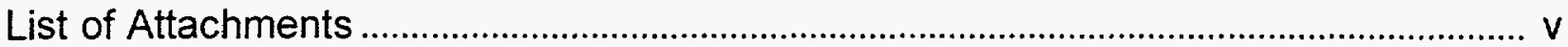

List of Abbreviations and Acronyms ............................................................................... vi

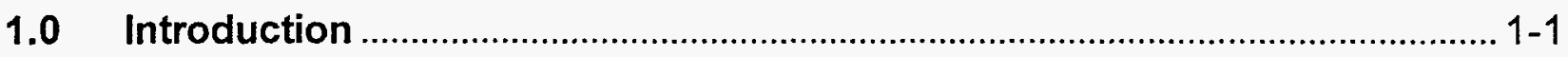

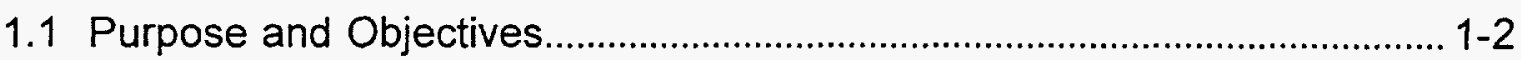

1.2 The "NEPA Process" .................................................................................. 1-3

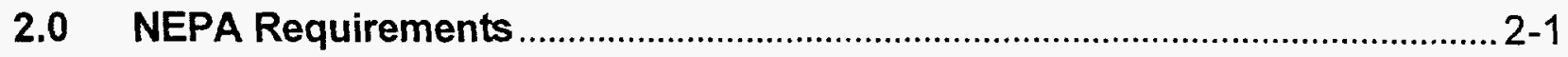

2.1 National Environmental Policy Act (NEPA) ............................................... 2-2

2.2 Council on Environmental Quality (CEQ) Regulations ..............................2-3

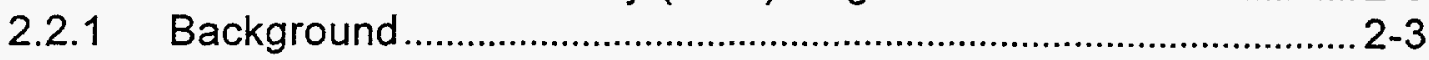

2.2.2 CEQ Regulations Highlights ...................................................... 2-4

2.3 U.S. Department of Energy (DOE) Regulations, Policy, and Guidance.... 2-7

2.3.1 DOE NEPA Implementing Procedures (10 CFR Part 1021),......2-7

2.3.2 Secretary of Energy's Policy Statement on NEPA ......................... 2-9

2.3.3 DOE Order 5440.1E and DOE Draft Order 491 ..........................2-12

2.3.4 DOE May 1993 EA/EIS Preparation Guidance (The "Green

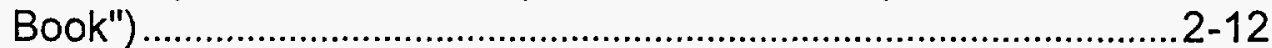

2.3.5 DOE Floodplains/Wetlands Review Requirements...................2-13

2.3.6 DOE-AL Environmental Assessment Quality Assurance Plan

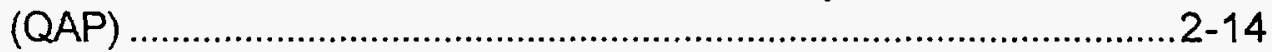

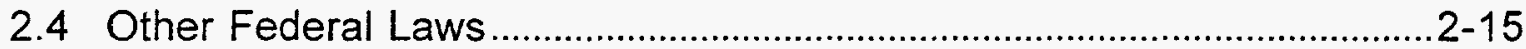

2.5 Other Federal Agency NEPA Requirements ...........................................2-16

3.0 NEPA Document Preparation Guidance …........................................................ 3-1

3.1 Environmental Checklist (ECL)/Action Description -Memorandum

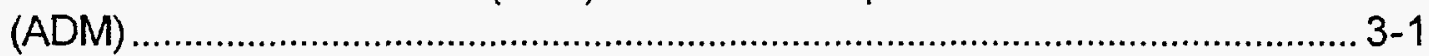

3.1.1 ECL/ADM Role in the NEPA Process .......................................... 3-3

3.1.2 ECL/ADM Step-By-Step Process................................................ 3-3

3.1.3 ECL/ADM Format and Content ..................................................... 3-7

3.1.4 ECL/ADM Review and Determination Time Requirements..........3-8

3.1.5 Public Participation/Disclosure .................................................... 3-9

3.2 Categorical Exclusion (CX) Determination ……........................................... 3-9

3.2.1 CX Step-By-Step Procedure ..........................................................3-10

3.2.2 Required Findings and Eligibility Criteria for a CX .......................3-11

3.2.3 Time Requirements .................................................................. $3-13$

3.2.4 Public Participation/Disclosure .................................................... $3-13$

3.3 Environmental Assessment (EA)........................................................ 


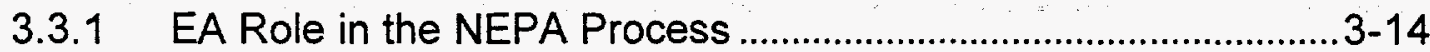

3.3.2 Proposed Actions "Normally" Requiring an EA ….........................3-14

3.3.3 Step-By-Step Preparation and Review..........................................3-16

3.3.4 EA Format and Content................................................................ 3-21

3.3.5 Page Limits..................................................................................... 3-24

3.3.6 Public Participation/Disclosure ....................................................3-24

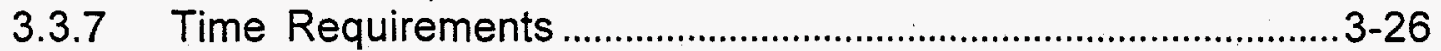

3.4 Finding of No Significant Impact (FONSI)...............................................3-27

3.4.1 FONSI Role in the NEPA Process ...............................................3-29

3.4.2 The "Mitigated" FONSI and MAP ................................................

3.4.3 Format and Content.......................................................................3-31

3.4.4 Public Participation/Disclosure ....................................................3-31

3.4.5 Time Requirements ...............................................................3-32

3.5 Environmental Impact Statement (EIS) .................................................3-32

3.5.1 EIS Role in the NEPA Process ....................................................3-33

3.5.2 Proposed Actions "Normally" Requiring an EIS............................3-34

3.5.3 Step-By-Step Preparation and Review...........................................3-34

3.5.4 Notice of Intent (NOI) ................................................................... 3-40

3.5.5 Public Scoping and Implementation Plan (IP) ...........................3-40

3.5.6 EIS Format and Content ..................................................................

3.5.7 EIS Page Limits.........................................................................

3.5.8 Programmatic and Sitewide EIS................................................. $3-47$

3.5.9 Supplemental EIS and Supplement Analysis ..............................3-49

3.5.10 Public Participation/Disclosure ....................................................3-49

3.5.11 Record of Decision (ROD) …......................................................

3.5.12 Time Requirements .................................................................

3.5.13 Recommendations for Increasing EIS Preparation Efficiency..3-53

4.0 Dealing With NEPA Documentation Problems ................................................. 4-1

4.1 - Document Writing and Preparation ..................................................................... 4-1

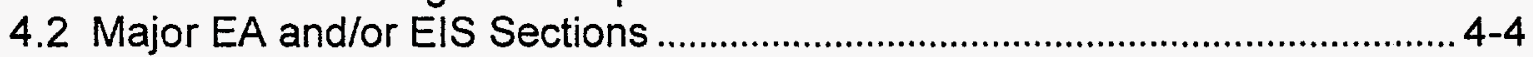

4.2.1 Purpose and Need for Action.......................................................... 4-4

4.2.2 Proposed Action and Alternatives............................................. 4-5

4.2.3 Affected Environment................................................................... 4-6

4.2.4 Environmental Consequences (Impact Analysis) ........................... 4-7

4.2.5 Cumulative Impacts.................................................................4-12

4.2.6 "Tiering" and "Bounding" ...............................................................4-14

4.2.7 Incomplete or Unavailable Information..........................................4-15

4.2.8 Mitigation Measures ......................................................................4-17 
Table of Contents (continued)

5.0 Special NEPA Compliance Issues

5.1 The NEPA Threshold Question: "Federalization" and "Defederalization".

5.2 NEPA/CERCLA/RCRA Document Integration. $5-4$

5.3 Environmental Justice. 5-5

5.4 Pollution Prevention. $5-8$

5.5 Air Conformity.

5.6 Biodiversity $5-13$

5.7 NEPA Exemptions $5-16$

5.8 Extraterritorial Applications of NEPA $5-19$

5.9 Segmentation

List of References

Glossary

Index 


\section{ATTACHMENT II}

\section{LIST OF PUBLISHED EAs AND EISs FOR SNL/NM}


List of Published EAs and EISs for SNL/NM

\begin{tabular}{|c|c|c|c|}
\hline$\overline{\text { Title }}$ & Identification Number & $\begin{array}{l}\text { Document } \\
\text { Date }\end{array}$ & $\begin{array}{c}\text { Date of FONSI or } \\
\text { ROD }\end{array}$ \\
\hline $\begin{array}{l}\text { Strategic Defenses Facility } \\
\text { Environmental Assessment }\end{array}$ & DOE/EA-0352 & July 1998 & July 26,1988 \\
\hline $\begin{array}{l}\text { Environmental Assessment for } \\
\text { the Robotics Manufacturing } \\
\text { Science and Engineering } \\
\text { Laboratory }\end{array}$ & DOE/EA-0885 & April 1994 & April 13, 1994 \\
\hline $\begin{array}{l}\text { Environmental Assessment for } \\
\text { the Neutron Generator/Switch } \\
\text { Tube (NG/ST) Prototyping Facility } \\
\text { Relocation }\end{array}$ & DOE/EA-0879 & April 1994 & April 8, 1994 \\
\hline $\begin{array}{l}\text { Nonnuclear Consolidation } \\
\text { Environmental Assessment, } \\
\text { Nuclear Weapons Complex } \\
\text { Reconfiguration Program }\end{array}$ & DOE/EA-0792 & June 1993 & July 8,1993 \\
\hline $\begin{array}{l}\text { Environmental Assessment for } \\
\text { the Radioactive and Mixed Waste } \\
\text { Management Facility }\end{array}$ & DOE/EA-0466 & June 1993 & April 23, 1993 \\
\hline $\begin{array}{l}\text { Kauai Test Facility Environmental } \\
\text { Assessment }\end{array}$ & DOE/EA-0492 & July 1992 & July 1,1992 \\
\hline $\begin{array}{l}\text { Environmental Assessment } \\
\text { Explosives Component Facility at } \\
\text { Sandia National Laboratories } \\
\text { Albuquerque, New Mexico }\end{array}$ & DOE/EA-0576 & July 1992 & July 10,1992 \\
\hline $\begin{array}{l}\text { Kauai Test Facility CDX Rocket } \\
\text { Operation Environmental } \\
\text { Assessment }\end{array}$ & DOE/EA-0786 & May 1992 & May 22, 1992 \\
\hline $\begin{array}{l}\text { Environmental Impact Statement } \\
\text { and Environmental Impact Report } \\
\text { for the Continued Operation of } \\
\text { Lawrence Livermore National } \\
\text { Laboratoryand Sandia National } \\
\text { Laboratories, Livermore }\end{array}$ & $\begin{array}{l}\text { DOE/EIS-0157 and } \\
\text { SCH90030847 }\end{array}$ & August, 1992 & January 27,1993 \\
\hline $\begin{array}{l}\text { Kauai Test Facility Two } \\
\text { Experiment Rocket Campaign } \\
\text { Environmental Assessment }\end{array}$ & DOE/EA-0492 & March 1991 & March 6, 1991 \\
\hline $\begin{array}{l}\text { Integrated Materials Research } \\
\text { Laboratory (IMRL) Environmental } \\
\text { Assessment }\end{array}$ & DOE/EA-0481 & January 1991 & January 3, 1991 \\
\hline $\begin{array}{l}\text { Final Supplemental Environmental } \\
\text { Impact Statement Waste Isolation } \\
\text { Pilot Plant }\end{array}$ & DOE/EIS-0026-FS & January 1990 & $\begin{array}{c}\text { June } 22,1990 \text { and } \\
\text { amended } \\
9 / 19 / \\
11 / 16 / \\
12 / 6\end{array}$ \\
\hline
\end{tabular}




\begin{tabular}{|c|c|c|c|}
\hline $\begin{array}{l}\text { Environmental Impact } \\
\text { Assessment Sandia } \\
\text { Laboratories Albuquerque, New } \\
\text { Mexico }\end{array}$ & EIAIMA 77-1 & May 1977 & $\begin{array}{l}\text { This document } \\
\text { predated the CEQ } \\
\text { FONSI }\end{array}$ \\
\hline $\begin{array}{l}5 \text { Megawatt Solar Thermal Test } \\
\text { Facility Environmental. } \\
\text { Assessment }\end{array}$ & & August 1976 & $\begin{array}{c}\text { This document } \\
\text { predated the CEQ } \\
\text { FONSI }\end{array}$ \\
\hline $\begin{array}{l}\text { Environmental Assessment } \\
\text { Tonopah Test Range }\end{array}$ & EIAMMA $76-2$ & $\begin{array}{l}\text { December } \\
1975\end{array}$ & $\begin{array}{l}\text { This document } \\
\text { predated the CEQ } \\
\text { FONSI } \\
\end{array}$ \\
\hline $\begin{array}{l}\text { Environmental Assessment of } \\
\text { General-Purpose Heat Source } \\
\text { (GPHS) Radioisotope } \\
\text { Thermoelectric Generator (RTG) } \\
\text { Safety Verification Testing }\end{array}$ & DOE/EA-1025 & $\begin{array}{l}\text { February } \\
1995\end{array}$ & February 13,1995 \\
\hline $\begin{array}{l}\text { Final Environmental Assessment } \\
\text { Gamma Irradiation Facility }\end{array}$ & DOE/EA-0973 & $\begin{array}{c}\text { November } \\
1995\end{array}$ & November 15,1995 \\
\hline $\begin{array}{l}\text { Environmental Assessment for } \\
\text { the Processing and } \\
\text { Environmental Technology } \\
\text { Laboratory (PETL) }\end{array}$ & DOE/EA-0945 & $\begin{array}{c}\text { September } \\
1995\end{array}$ & December 18,1995 \\
\hline $\begin{array}{l}\text { Environmental Assessment of } \\
\text { the Environmental Restoration } \\
\text { Project at Sandia National } \\
\text { Laboratories/New Mexico }\end{array}$ & DOEJEA-1140 & $\begin{array}{l}\text { March } \\
1996\end{array}$ & March 25, 1996 \\
\hline $\begin{array}{l}\text { Environmental Assessment for } \\
\text { Operations, Upgrades, and } \\
\text { Modifications in SNL Technical } \\
\text { Area IV }\end{array}$ & DOE/EA-1153 & April 1996 & April 4, 1996 \\
\hline $\begin{array}{l}\text { Environmental Assessment for } \\
\text { Sandia National } \\
\text { Laboratories/New Mexico Offsite } \\
\text { Transportation of Low-level } \\
\text { Radioactive Waste. }\end{array}$ & DOE/EA-1180 & $\begin{array}{l}\text { September } \\
1996\end{array}$ & November 20.1996 \\
\hline $\begin{array}{l}\text { Final Environmental Impact } \\
\text { Statement for the Nevada Test } \\
\text { Site and Off-site Locations in the } \\
\text { State of Nevada }\end{array}$ & DOEEIS-0243 & August 1996 & December 9, 1996 \\
\hline $\begin{array}{l}\text { Final Programmatic Environmental } \\
\text { Impact Statement for Stockpile } \\
\text { Stewardship and Management }\end{array}$ & DOE/EIS-0236 & $\begin{array}{l}\text { September } \\
1996\end{array}$ & December 19, 1996 \\
\hline
\end{tabular}




\begin{tabular}{|l|l|l|c|}
\hline $\begin{array}{l}\text { Final Waste Management } \\
\text { Programmatic } \\
\text { Environmental Impact Statement } \\
\text { For Managing Treatment, } \\
\text { Storage, and Disposal of } \\
\begin{array}{l}\text { Radioactive and Hazardous } \\
\text { Waste }\end{array}\end{array}$ & DOEJEIS-0200-F & May 1977 & May 29, 1998, and \\
\hline $\begin{array}{l}\text { Environmental Assessment of } \\
\text { the Sandia National Laboratories } \\
\text { Design, Evaluation, and Test } \\
\text { Technology Center at Technical } \\
\text { Area III Kirtland Air Force Base } \\
\text { Albuquerque, New Mexico }\end{array}$ & DOEJEA-1195 & $\begin{array}{l}\text { April } \\
1997\end{array}$ & April 18, 1997 \\
\hline
\end{tabular}




\section{ATTACHMENT III}

Abstracts of Published Reports and Journal Articles 
Cohen, T. M. and D. R. Bleakly, 1997,Addressing Environmental Justice Under the National Environmental Policy Act at Sandia National Laboratories/New Mexico SAND 97-0869.

\section{ABSTRACT:}

"Under Executive Order 12898, federal Actions to Address Environmental Justice in Minority Populations and Low-Income Populations, the Department of Energy and Sandia National Laboratories/New Mexico (SNL) are required to identify and address, as appropriate, disproportionately high, adverse human health or environmental effects of their activities on minority and low-income populations. The National Environmental Policy Act (NEPA) also requires that environmental justice issues be identified and addressed. This presents a challenge for SNL because it is located in a culturally diverse area. Successfully addressing potential impacts is contingent upon accurately identifying them through objective analysis of demographic information. However, an effective public participation process, which is necessarily subjective, is also needed to understand the subtle nuances of diverse populations that can contribute to a potential impact, yet are not always accounted for in a strict demographic profile. Typically, there is little or no coordination between these two disparate processes. This report proposes a five-step method for reconciling these processes and uses a hypothetical case study to illustrate the method. A demographic analysis and community profile of the population within 50 miles of SNL were developed to support the environmental justice analysis process and enhance SNL's NEPA and public involvement programs. This report focuses on developing a methodology for identifying potentially impacted populations. Environmental justice issues related to worker exposures associated with SNL activities will be addressed in a separate report."

Fischer, N. T., International Technology Corporation, 1990, Revision of Species Inventory Checklists for Sandia National Laboratories, Albuquerque Bernalillo County, New Mexico SAND 93-7098.

\section{ABSTRACT:}

"This report revises and updates the 1974 report by W. C. Martin and W. L. Wagner, Biological Survey of Kirtland Air Force Base (East). The biological communities of Kirtland Air Force Base (KAFB) are described with respect to the Biome classification system of Brown (1982), and a standardized system of habitat types is proposed based on biome and soil type. The potential occurrence of State or Federally endangered species is discussed. No species listed as endangered or threatened is known to occur on KAFB, although five are identifies as potentially occurring. Updated lists of amphibians, reptiles, breeding birds, mammals, and plants are presented." 
W. M. Gutman, and R. J. Silver, 1994, Air Quality Investigations of the Sandia National Laboratories Sol se Mete Aerial Cable Facility SAND 93-7094.

\section{ABSTRACT}

"The air quality implications of the test and evaluation activities at the Sandia National Laboratories Sol se Mete Aerial Cable Facility are examined. All facets of the activity that affect air quality are considered. Air Contaminants produced directly include exhaust products of rocket motors used to accelerate test articles, dust and gas from chemical explosives, and exhaust gases from electricity generators in the test arenas. Air contaminants produced indirectly include fugitive dust and exhaust contaminants from vehicles used to transport personnel and material to the test area, and effluents produced by equipment used to heat the project buildings. Both the ongoing program and the proposed changes in the program are considered. Using a reliable estimate of the maximum annual testing level, the quantities of contaminants are predicted using EPA dispersion models. The predicted quantities and concentrations are evaluated in relation to Federal, New Mexico, and the Bernalillo air quality regulations and the human health and safety standards of the American Conference of Governmental Industrial Hygienists."

\section{Hansen, R. P., 1995, National Environmental Policy Act (NEPA) Compliance Guide Sandia National} Laboratories SAND95-1648.

\section{ABSTRACT}

"This report contains a comprehensive National Environmental Policy Act (NEPA) Compliance Guide for the Sandia National Laboratories. It is based on the Council on Environmental Quality (CEQ) NEPA regulations in 40 CFR Parts 1500 through 1508; the U.S. Department of Energy (DOE) NEPA implementing procedures in 10 CFR Part 1021; DOE Order 5440.1E; the DOE "Secretarial Policy Statement on the National Environmental Policy Act" of June 1994; Sandia NEPA compliance procedures; and other CEQ and DOE guidance. The Guide includes step-by-step procedures for preparation of Environmental Checklists/Action Descriptions Memoranda (ECL/ADMs), Environmental Assessments (EAs), and Environmental Impact Statements (EISs). It also includes sections on "Dealing With NEPA Documentation Problems" and "Special NEPA Compliance Issues."'

Hansen, R. P., 1992, NEPAVERCLAVRCRA Integration Strategy for Environmental Restoration Program Sandia National Laboratories, Albuquerque SAND92-7312.

\section{ABSTRACT:}

"This report addresses an overall strategy for complying with DOE Order 5400.4 which direct that DOE offices and facilities integrate the procedural and documentation requirements of the Comprehensive Environmental Response, Compensation, and Liability Act (CERCLA) and the National Environmental Policy Act (NEPA) where practical and appropriate. Integration of NEPA and Resource Conservation and Recovery Act (RCRA) processes is emphasized because RCRA applies to most of the potential release sites at SNL, Albuquerque. NEPA, CERCLA, and RCRA processes are comparatively analyzed and special integration issues are discussed. Three integration strategy options are evaluated and scheduling and budgeting needs are identified. An annotated outline of an integrated project-or site-specific NEPARCRA RFI/CMS EIS or EA is included as an appendix." 
R. P. Hansen and T. Wolff, 1993, "NEPAVCERCLA/RCRA Integration: Policy Vs Practice" in Proceedings of the 1993 Conference of the National Association of Environmental Professionals, Current and Future Priorities for Environmental Management, May 24-26, Raleigh, North Carolina.

ABSTRACT:

"Overwhelmed with environmental protection documentation requirements, a number of Federal agencies are grappling with the complexities of attempting to "integrate" the documentation requirements of the National Environmental Policy Act (NEPA), the Comprehensive Environmental Response, Compensation, and Liability Act (CERCLA), and the Resource Conservation and Recovery Act (RCRA). While there is some overlap between the general environmental policy objectives of NEPA, and the much more specific waste cleanup objectives of CERCLA and RCRA, there are also major differences and outright conflicts. For example, there is always the possibility that NEPA compliance requirements can result in delaying the cleanup of sites posing an endangerment to the public health and welfare and the environment.

This paper identifies both problems and opportunities associated with implementing emerging and evolving Federal agency policy regarding integration of the procedural and documentation requirements of NEPA, CERCLA, and RCRA. The emphasis is on NEPAVERCLAVRCRA integration policy and practice at U.S. Department of Energy (DOE) facilities. The paper provides a comparative analysis of NEPA, CERCLA, and RCRA processes and discusses special integration issues including scoping, development and analysis of alternatives, risk assessment, tiering, scheduling, and the controversy surrounding applicability of NEPA to CERCLA or RCRA cleanup activities. Several NEPAVCERCLAVRCRA integration strategy options are evaluated and an annotated outline of an integrated NEPAVERCLA document is included."

R. P. Hansen and T. Wolff, 1998, "Streamlining the Process: A Strategy for Making NEPA Work Better and Cost Less" in Proceedings of the 23 Annual Conference of the National Association of Environmental Professionals, The Environment and the Pacific Rim, May 20-26, San Diego, California.

ABSTRACT:

"When the National Environmental Policy Act (NEPA) was enacted in 1969, neither Congress nor the Federal Agencies affected anticipated that implementation of the NEPA process would result in the intolerable delays, inefficiencies, duplication of effort, commitments of excessive financial and personnel resources, and bureaucratic gridlock that have become institutionalized. The 1978 Council on Environmental Quality (CEQ) regulations, which were intended to make the NEPA process more efficient and more useful to decision makers and the public, have either been largely ignored or unintentionally subverted. Agency policy mandates, like those of former Secretary of Energy Hazel R. O'Leary, to "make NEPA work better and cost less" have, so far, been disappointingly ineffectual. Federal Agencies have reached the point where almost every constituent of the NEPA process must be subjected to crisis management.

This paper focuses on a 10-point strategy for "streamlining" the NEPA process in order to achieve the Act's objectives while easing the considerable burden on agencies, the public, and the judicial system. How the 10 points are timed and implemented is critical to any successful streamlining. 
The strategy elements discussed in this paper, in no particular order of priority, are as follows: (1) integrate the NEPA process with other environmental compliance and review procedures; (2) accelerate the decision time for determining the appropriate level of NEPA documentation; (3) conduct early and thorough internal EIS (or EA) scoping before public scoping or other public participation begins; (4) organize and implement public scoping processes that are more participatory than confrontational; (5) maintain an up-to-date compendium of environmental "baseline" information; (6) prepare more comprehensive, broad-scope "umbrella" and "site-wide" EISs that can be used effectively for tiering; (7) encourage preparation of annotated outlines with detailed guidance that serve as a "road map" for preparation of each EIS or EA; (8) decrease the length and complexity of highly technical portions of NEPA documents; (9) increase and systematize NEPA compliance outreach, training, and organizational support; and (10) work diligently to influence the preparation of better organized, shorter, and more readable NEPA documents."

Hansen, R. P., T. A Wolff, and Lance N McCold, 1997, "The Conflict of Interest Problem in EIS Preparation" in: Proceedings of the 1997 Conference of the National Association of Environmental Professionals May 19-22, Orlando, Florida.

ABSTRACT:

"The National Environmental Policy Act (NEPA) requires that federal agencies prepare environmental impact statements (EISs) on proposals for "major federal action significantly affecting the quality of the human environment." The Council on Environmental Quality (CEQ) regulations require that EISs be prepared directly by the "lead agency" or a contractor it selects. EIS contractors must execute a disclosure statement specifying that they have "no financial or other interest" in the outcome of the project. The intent of the "conflict of interest" prohibition is to ensure that the EIS is defensible, free of self-serving bias, and credible to the public. Those coming to the federal government for money, permits, or project approvals must not be placed in the position of analyzing the environmental consequences of their own proposals.

Although the conflict of interest proscription may seem clear and unequivocal, it has generated confusion and controversy as evidenced by litigation of the issue in the federal courts. In fact, the CEQ has twice provided conflict of interest guidance and some critics feel that the provision should be completely eliminated from the regulations

This paper analyzes the conflict of interest problem faced by government contractors who maintain and operate government-owned or -controlled facilities for which EISs are required. In the U.S. Department of Energy (DOE) system, these are referred to as " $M \& O$ " contractors. It also examines organizational conflicts presented by current or prospective government contractors who have a financial or other interest in the outcome of a project or program for which an EIS is prepared. The paper addresses several key questions: What constitutes a conflict within the meaning of the CEQ regulations? Are contractor personnel more likely to experience conflicts of interests than agency personnel who are responsible for the project or program? If a conflict exists, is an M\&O or other contractor disqualified from participating in the NEPA process (e.g., by providing background papers and technical data)? What type of "participation" might be permitted without presenting a conflict risk?

In responding to these and related questions, the paper discusses and interprets the CEQ regulations and guidance on EIS preparation conflict of interest as well as leading federal court opinions. It also distinguishes "preparers" from "participants" in the EIS preparation process. While the focus is on discussion and interpretation of the CEQ requirements, 
brief attention is also given to conflict provisions in Federal Acquisition Requirements (FAR) which go beyond the CEQ conflict provisions. Conclusions drawn are intended to provide guidance as to the kind of conflict disclosures and NEPA process roles appropriate for EIS preparers and participants."

Harris, J. M., 1995, "Integrating National Historic Preservation Act Compliance into the National Environmental Policy Act Process" in: Proceedings of the National Association of Environmental Professionals (NAEP) 20th Annual Conference Proceedings "Environmental Challenges: The Next 20 Years June 10-14, Washington, D.C.

ABSTRACT:

"The National Historic Preservation Act (NHPA) of 1966 placed requirements on federal Agencies regarding the identification and use of Historic Properties. The Council of Environmental Quality regulations implementing the National Environmental Policy Act (NEPA) of 1969 (40 CFR 1502.25) encourage the concurrent preparation of NEPA documents with other review and consultation requirements, including NHPA. The Department of Energy (DOE) recognizes the desirability of coordination of NEPA with other environmental review requirements in its NEPA implementing regulations (10 CFR 1021.341).

Sandia National Laboratories is a government-owned contractor-operated research and development laboratory within the DOE complex. Compliance with NHPA was formerly coordinated through Facilities Engineering, but is now being coordinated through the Risk Management and NEPA Department. Although the requirements of NHPA and NEPA can be met separately and independently, this paper will discuss the value added by integration and coordination of NHPA requirements with the NEPA process.

Overall, integration of NHPA and NEPA has led to improved compliance with both requirements. Integration of requirements can decrease the elapsed time for compliance activities by allowing the two processes to proceed in parallel rather than in sequence. NHPA Section 106 consultations are primarily associated with undertakings involving ground disturbance such as environmental restoration, and construction and modification activities, but NHPA compliance activities is also explicitly considered for research, development, and testing activities. The requirements of NHPA, for a particular SNL project, are identified through initial NEPA review. It has been our experience that SNL "actions" under NEPA are often not "undertakings" under NHPA, but that usually an SNL "undertaking" is also an "action."'

Harris, J. M., 1995, Annotated Bibliography of National Environmental Policy Act (NEPA) Documents for Sandia National Laboratories SAND94-2032.

ABSTRACT:

"The following annotated bibliography lists documents prepared by the Department of Energy (DOE), and predecessor agencies, to meet the requirements of the National Environmental Policy Act (NEPA) for activities and facilities at Sandia National Laboratories sites. For each NEPA document summary information and a brief discussion of content is provided. This information may be used to reduce the amount of time or cost associated with NEPA compliance for future Sandia National Laboratories projects. This summary may be used to identify model documents, documents to use as sources of information, or documents from which to tier additional NEPA documents." 
Hoagland, S. R. and K. J. Lord 1993, Cultural Resources Regulatory Analysis, Area Overview, and Assessment of Previous Department of Energy and Kirtland Air Force Base Inventories for Sandia National Laboratories, SAND92-7345.

\section{ABSTRACT:}

"On September 1, 1989, Sandia National Laboratories (SNL) contracted Chambers Group Inc. (CGI) to provide consulting services in the areas of archaeological research and investigation, architectural and historic resource identification and preservation, and related regulatory analysis and coordination as required to facilitate SNL's compliance with all applicable laws, regulations, guidelines and policies governing properties controlled by the U.S. Department of Energy (DOE), and occupied by SNL. The contract involved the production of a regulatory analysis and literature review of archaeological and historic resources on the SNL-occupied properties. The contract was amended on February 28,1991 , to encompass production of a document to be used to facilitate future project planning, environmental assessments, and the protection of significant cultural resources.

This document included the regulatory discussion and, based on the literature review, a brief overview of known historic and prehistoric resource utilization at SNL, Kirtland Air Force Base (KAFB) and vicinity. It also contained details of the work conducted on DOE controlled lands and a generalization of previous work conducted on KAFB and United States Forest Service (USFS) Withdrawal Lands. To aid in this discussion a map depicting previously inventoried locales and a corresponding table detailing the results were to be produced. Finally, there was a discussion by general areas at SNL, KAFB, and USFS Withdrawal Lands as to their potential for containing significant cultural resources. This report is the document produced in response to the above noted contract requirements."

IT Corporation, 1996, Sandia National Laboratories/New Mexico Environmental Baseline UpdateRevision 1.0 SAND96-1608.

ABSTRACT

"The purpose of this Sandia National Laboratories/New Mexico (SNL/NM) Environmental Baseline Update is to provide the background information necessary for SNLNM personnel and contractors to prepare clear and concise NEPA documentation. The scope of the Environmental Baseline Update is to provide comprehensive data needed to support a description of the affected environment at the SNL/NM facility. The "description of the affected environment," required by the CEQ regulations in 40 CFR $\$ 1502.15$, is an essential prerequisite for assessing the environmental consequences ( $\$ 1502.18)$ of a proposed action (project) to be implemented by SNL/NM."

March, F., 1996, "Determining the Significance of Proposed Actions" in: Proceedings of the 1996 National Association of Environmental Professionals (NAEP), Practical Environmental Directions: A Changing Agenda, Houston, Texas, June 2-6.

\section{ABSTRACT:}

"The concept of significance of environmental impact is at the heart of NEPA practice. Most important, significance is the threshold criterion which determines when an Environmental Impact Statement (EIS) is required as well as the depth of study of each 
issue within an EIS. This paper examines the concept of significance and identifies some problems in applying it in actual NEPA practice. A systematic framework is provided for formal application when answering the threshold question, and when scoping an EIS. Finally a specific procedure is recommended for determining what evidence of impact is needed to evaluate significance and how to apply NEPA's criteria in determining significance. This approach provided in this paper has been proposed to the NEPA Practice Committee of NAEP for formal adoption as a recommended Practice."

Martin, W. C. and W. L. Wagner, 1974, Biological Survey of Kirtland Air Force Base (East), SAND74-0393, Sandia National Laboratories, Albuquerque, New Mexico.

\section{ABSTRACT:}

"This survey provides an annotated checklist of the species of flora and fauna whose patterns of distribution extend into this area. Also presented is a classification of the vegetational and animal associations occurring in the area surveyed, and a correlation of these associations with the plant communities of the southwestern United States."

Matise, B. K., W. M. Gutman, R. A. Cunniff, R. J. Silver, and W. E. Stepp, 1994, "Noise and Vibration Investigations of the Sandia National Laboratories Sol se Mete Aerial Cable Facility" SAND93-7095.

\section{ABSTRACT:}

"The noise and vibration effects and fragmentation hazards of the test and evaluation activities at the Sandia National Laboratories Sol se Mete Aerial Cable Facility are investigated. The predominant contributor to the existing noise environment is the operation of aircraft arriving at or departing from Albuquerque International Airport. The Airport is jointly used by civilian aircraft and military aircraft operating from the adjacent Kirtland Air Force Base. Noise sources associated with the Aerial Cable facility are examined in detain. Both the ongoing program and construction that would be require for the proposed additions to the facilities are investigated. Project related noise sources include vehicles, tests involving detonation of high explosives, rocket motors, a 3-inch gun, and a $20 \mathrm{~mm}$ gun. Noise predictions are made by scaling noise values from handbooks and other reference sources to the appropriate distances. Ground vibration, overpressure, and fragmentation are predicted using standard scaling laws. Predicted noise levels for specific Aerial Cable Facility activities are used to estimate the equivalent sound level for the 8-hour work day and to determine when worker hearing protection is necessary. Hazard radii for tests involving high explosives also are given."

R. M. Sullivan \& P. J. Knight, 1994, Biological Surveys for the Sandia National Laboratories Coyote Canyon Test Complex Kirtland Air Force Base Albuquerque, New Mexico SAND93-7089.

\section{ABSTRACT:}

"This study summarizes results of biological field investigations of the SNL/NM Aerial Cable Site (ACS), at the east end of KAFB, Bernalillo County, New Mexico. ACS occupies a 440 acre tract of land withdrawn by the U.S. Forest Service for use by KAFB, and in turn placed under operational control of SNL/NM. In addition, SNL/NM uses roadways and other land adjoining the dedicated 440-acre tract. All land used by SNL/NM for the ACS is part of a 15,851-acre tract of land withdrawn by the U.S. Forest service. There also are a number of different organizations that use the 15,851-acre 
area, including KAFB, other SNL/NM users, different departments within the Department of Energy (DOE), and the Department of Transportation.

Information contained in this document is a result of literature research, consultation with the U.S. Fish and Wildlife Service, the U.S. Forest Service, the New Mexico Energy and Natural Resources Department, the New Mexico Department of Game and Fish, and on-site biological field surveys. Information on Threatened, Endangered, and Sensitive species potentially or actually occurring in the project area, as listed by the federal government and the New Mexico Department of Game and Fish, is also included.

The purposes of the field survey were to determine the existing and potentially existing plant and wildlife species in the project area and to identify sensitive wildlife habitats (i.e., travel corridors, foraging areas, nesting sites, sensitive species habitat, etc.).

Additionally, the survey was designed to ensure that future projects within the ACS will not result in adverse impacts to sensitive species actually or potentially occurring in the immediate area. Impacts to the existing environment resulting from possible future use of the area by military personnel and SNL/NM were evaluated and recommended guidelines to alleviate or minimize these impacts are discussed.

This report has been prepared for use as a planning document for consideration of all operations of the ACS and associated test facilities. Its implementation is in complete accordance with the 1985 Cibola National Forest Master Plan (and 1991 Proposed Amendment), and the New Mexico Department of Game and Fish Recommendations for Wildlife Baseline Study Guidelines for Construction Projects (May 1990). Potential impacts are discussed in both a specific and general case, as are the mitigation guidelines. This document, therefore, can serve as a general guide for future land planning and resource assessment if supplemented with additional detailed biological assessments that address potential impacts on specific projects at SNL/NM."

Sullivan, R. M.1994, Biological Investigations of the Sandia National Laboratories Sol se Mete Aerial Cable Facility" SAND93-7093.

ABSTRACT:

"This study summarizes results of biological field investigations of the SNL/NM Aerial Cable Site (ACS), at the east end of KAFB, Bernalillo County, New Mexico. ACS occupies a 440 acre tract of land withdrawn by the U.S. Forest Service for use by KAFB, and in turn placed under operational control of SNL/NM. In addition, SNL/NM uses roadways and other land adjoining the dedicated 440-acre tract. All land used by SNL/NM for the ACS is part of a 15,851-acre tract of land withdrawn by the U.S. Forest service. There also are a number of different organizations that use the 15,851-acre area, including KAFB, other SNL/NM users, different departments within the Department of Energy (DOE), and the Department of Transportation.

Information contained in this document is a result of literature research, consultation with the U.S. Fish and Wildlife Service, the U.S. Forest Service, the New Mexico Energy and Natural Resources Department, the New Mexico Department of Game and Fish, and on-site biological field surveys. Information on Threatened, Endangered, and Sensitive species potentially or actually occurring in the project area, as listed by the federal government and the New Mexico Department of Game and Fish, is also included.

The purposes of the field survey were to determine the existing and potentially existing plant and wildlife species in the project area and to identify sensitive wildlife habitats (i.e., 
travel corridors, foraging areas, nesting sites, sensitive species habitat, etc.). Additionally, the survey was designed to ensure that future projects within the ACS will not result in adverse impacts to sensitive species actually or potentially occurring in the immediate area. Impacts to the existing environment resulting from possible future use of the area by military personnel and SNL/NM were evaluated and recommended guidelines to alleviate or minimize these impacts are discussed.

This report has been prepared for use as a planning document for consideration of all operations of the ACS and associated test facilities. Its implementation is in complete accordance with the 1985 Cibola National Forest Master Plan (and 1991 Proposed Amendment), and the New Mexico Department of Game and Fish Recommendations for Wildlife Baseline Study Guidelines for Construction Projects (May 1990). Potential impacts are discussed in both a specific and general case, as are the mitigation guidelines. This document, therefore, can serve as a general guide for future land planning and resource assessment if supplemented with additional detailed biological assessments that address potential impacts on specific projects at SNL/NM."

Wolff, T. A. and R. P. Hansen, 1996, "Tools for NEPA Compliance: Baseline Reports and Compliance Guides" in: Proceedings of the 1996 Conference of the National Association of Environmental Professionals, Practical Environmental Directions: A Changing Agenda," Houston, Texas, June 2-6.

ABSTRACT:

"The Council on Environmental Quality's regulations on implementing the National Environmental Policy Act (NEPA) in 40 CFR Part 1508 (Terminology and Index) do not include environmental baseline reports or compliance guides designed to implement NEPA in the definition of "environmental document." Nevertheless, these documents are essential tools for effective NEPA compliance.

Baseline reports that support NEPA Documents include environmental monitoring reports, cultural resources reports, and reports on the occurrence and distribution of biological resources. Such reports can provide a repository of detailed information on the affected environment, allow agencies to focus in "environmental documents" on significant environmental issues and alternatives, and reduce the accumulation of extraneous background date in NEPA documents. In addition, at multidisciplinary facilities such as Sandia National Laboratories (Sandia) the existence of detailed baseline reports prior to the existence of a proposal for a new project or facility provides the "building blocks" from which good environmental documents can be efficiently produced. At Sandia we published an omnibus NEPA environmental baseline report in 1993. We intend it to be a "living document," to be periodically updated to reflect the current status of Sandia's environmental conditions at its main New Mexico facilities. The report provides a summary of existing information as a foundation for building environmental documents. NEPA documents require a description of the affected environment. Such a description is an essential prerequisite for assessing the environmental consequences of proposed actions to be implemented. For new assessments, the report's "boilerplate," may be used in the description of the affected environment. The report may also serve as a springboard for the gathering, when required, of more extensive project specific data The document's annotated bibliography provides a detailed source of information and is intended to facilitate further investigation. Although our NEPA baseline report was aimed a providing a baseline environmental information for writers of NEPA documents, the report is also useful as a source document for other environmental reports and regulatory submittals. 
NEPA compliance guides provide "roadmaps" for compliance. At Sandia we have prepared a two volume compliance guide that reviews and analyzes relevant NEPArelated laws and regulations (e.g., 40 CFR Parts 15-00-1508), DOE NEPA Guidance Sandia NEPA guidance, relevant Executive Orders, and other pertinent guidance.

Both our NEPA baseline report and NEPA compliance guide are invaluable resources in efficiently and effectively supporting NEPA compliance. This paper details our experience in developing these documents, our views on their proper use, and outlines the topics that we believe should be included in such documents."

Wolff, T. A. and R. P. Hansen, 1994, "Use of Comprehensive NEPA Documents to Reduce Program Risk" in: Proceedings of the 1994 Conference of the National Association of Environmental Professionals, Global Strategies for Environmental Issues, New Orleans, Louisiana, June 12-15.

ABSTRACT:

"Sandia National Laboratories operates DOE's Kauai Test Facility (KTF) on the western coast of the Hawaiian island of Kauai. In July 1992, DOE approved a comprehensive Environmental Assessment (EA) covering ongoing and future rocket launches of experimental payloads.

The successful completion of this complex assessment resulted in these benefits:

Integration of regulatory compliance requirements

Reduction in project delays through simultaneous approval of ongoing and foreseeable actions

Facilitation of the use of appropriate categorical exclusions

Reduction of the risk of litigation by avoiding segmentation

Provision of the opportunity for credible cumulative impact analysis.

The KTF EA, as do all properly crafted NEPA documents, fulfilled two basic objectives:

Consideration of environmental values early in the planning and decision making process

Public disclosure.

These objectives can also be considered to be benefits of preparing comprehensive NEPA documents. However, proponents of an action are not as dedicated to these twin NEPA objectives as they are motivated by NEPA's ability to reduce program risks. Once the KTF environmental assessment was underway, it was apparent that reducing risks to the program, budget, and schedule was the main incentive for successful completion of the EA.

The comprehensive or "omnibus" environmental assessment prepared for the KTF is a de facto "detailed statement," and it is also a good example of a "mitigated FONSI," i.e., mitigation measures are essential to render some potential impacts not significant. Because the KTF EA is a broad scope, umbrella-like, site-wide assessment, it "bounds" the impacts of continuing and proposed future actions. The successful completion of this document eliminated the need to review, document, and gain approval individually for numerous related actions. Also, because it supported a Finding of No Significant Impact 
(FONSI) after identifying appropriate mitigation, it also eliminated the need for an environmental impact statement (EIS)."

Wolff, T. A. and R. P. Hansen, 1993, "The NEPA Threshold Question Revisited: Proposed "Actions and. Continuing Activities" in Proceedings of the 1993 Conference of the National Association of Environmental Professionals, Current and Future Priorities for Environmental Management, Raleigh, North Carolina, May 24-26.

\section{ABSTRACT:}

"The National Environmental Policy Act (NEPA) requires federal agencies to include a "detailed statement" in every recommendation or report on "proposals" for "major federal action significantly affecting the quality of the human environment. Unless the three elements of a proposal are present (major, federal, and action), preparation of a detailed statement is not required.

Since 1970, dozens of Federal court decisions have addressed what has become known as the NEPA "threshold" requirement and have repeatedly defined the terms "proposal," "major," "Federal action," and "significant." The Council on Environmental Quality (CEQ) NEPA implementing regulations, in defining these threshold terms, do not consider "major" to have a meaning independent of "significant." Thus, the initial trigger for a detailed statement is a Federal action. However, it is the "significance" issue that has received most of the attention in the NEPA literature.

This paper addresses the practical decision making dilemma that attends determination of what types of Federal activities meet the NEPA threshold test under what kinds of varying circumstances. The authors' experiences with U.S. Department of Energy (DOE) NEPA documentation is used to discuss how decisions may be made to determine whether a proposed action qualifies for a "categorical exclusion" or whether it requires an environmental assessment (EA) or an environmental impact statement (EIS). The concept of "new" actions versus "continuing" actions which may be "bounded" by previous NEPA documentation is also discussed. A dichotomous key for separation or combining "Federal action" candidates for different levels of NEPA documentation is provided in the following table. Leading court opinions on the threshold question and related issues are discussed in lay terms." 
Distribution:

Copies Recipient

1

Gary Palmer

DOE Environmental Support (DP-45)

1000 Independence Ave. S. W.

Washington, D. C. 20585-0104

2

George Laskar

Assistant Area Manager

U.S. Department of Energy

Environment, Safety and Health

DOE Kirtland Area Office

MS 0184

5

Susan Lacy

U.S. Department of Energy

Environment, Safety and Health

DOE Kirtland Area Office

MS 0184

1

Jeff Robbins

U.S. Department of Energy

DOE/AL/EPD.

10

Roger P. Hansen

Hansen Environmental Consultants

6439B South Havana St.

Englewood, Co 80111-5618 


$\begin{array}{lll}1 & \text { MS 0315 } & \text { R. G. Hay, 2419 } \\ 1 & \text { MS0315 } & \text { A. A. Lopez 2419 } \\ 1 & \text { MS 0749 } & \text { T. M.Cohen, 6217 } \\ 1 & \text { MS 1054 } & \text { T. E. Blejwas, 7500 } \\ 1 & \text { MS 1043 } & \text { L. Mayeux, 7511 } \\ 3 & \text { MS0369 } & \text { A. O. Bendure, 7523 } \\ 1 & \text { MS 0369 } & \text { P. R. Fleming, 7523 } \\ 1 & \text { MS 0369 } & \text { F. March, 7523 } \\ 1 & \text { MS 0369 } & \text { J. V.Guerrero, 7523 } \\ 1 & \text { MS 0854 } & \text { Hu-Su Hwang, 7575 } \\ 1 & \text { MS 0369 } & \text { J. M. Harris, 7575 } \\ 1 & \text { MS 0369 } & \text { G. L. Gentry, 7575 } \\ 1 & \text { MS 01412 } & \text { E. D. Krauss, 11300 } \\ 1 & \text { MS 0111 } & \text { D. D. Carson, 12600 } \\ 1 & \text { MS 1313 } & \text { M. D. DeWitte, 12650 } \\ 15 & \text { MS 1313 } & \text { T. A. Wolff, 12650 } \\ 1 & \text { MS 1313 } & \text { L. H. Schluter } \\ 1 & \text { MS } 9018 & \text { Central Technical Files, 8940-2 } \\ 2 & \text { MS 0899 } & \text { Technical Library, 4916 } \\ 2 & \text { MS 0100 } & \text { Document Processing, 7613-2 } \\ 1 & \text { MS 0619 } & \text { Review and Approval Desk for DOE/OSTI, 12690 }\end{array}$

